Andrews University

Digital Commons @ Andrews University

2011

\title{
A Model for Enhanced Nurture of New Believers in the Reang Tribe in India
}

Lalmuansanga Chawngthu

Andrews University

Follow this and additional works at: https://digitalcommons.andrews.edu/dmin

Part of the Practical Theology Commons

\section{Recommended Citation}

Chawngthu, Lalmuansanga, "A Model for Enhanced Nurture of New Believers in the Reang Tribe in India" (2011). Professional Dissertations DMin. 542.

https://dx.doi.org/10.32597/dmin/542

https://digitalcommons.andrews.edu/dmin/542

This Project Report is brought to you for free and open access by the Graduate Research at Digital Commons @ Andrews University. It has been accepted for inclusion in Professional Dissertations DMin by an authorized administrator of Digital Commons @ Andrews University. For more information, please contact repository@andrews.edu. 


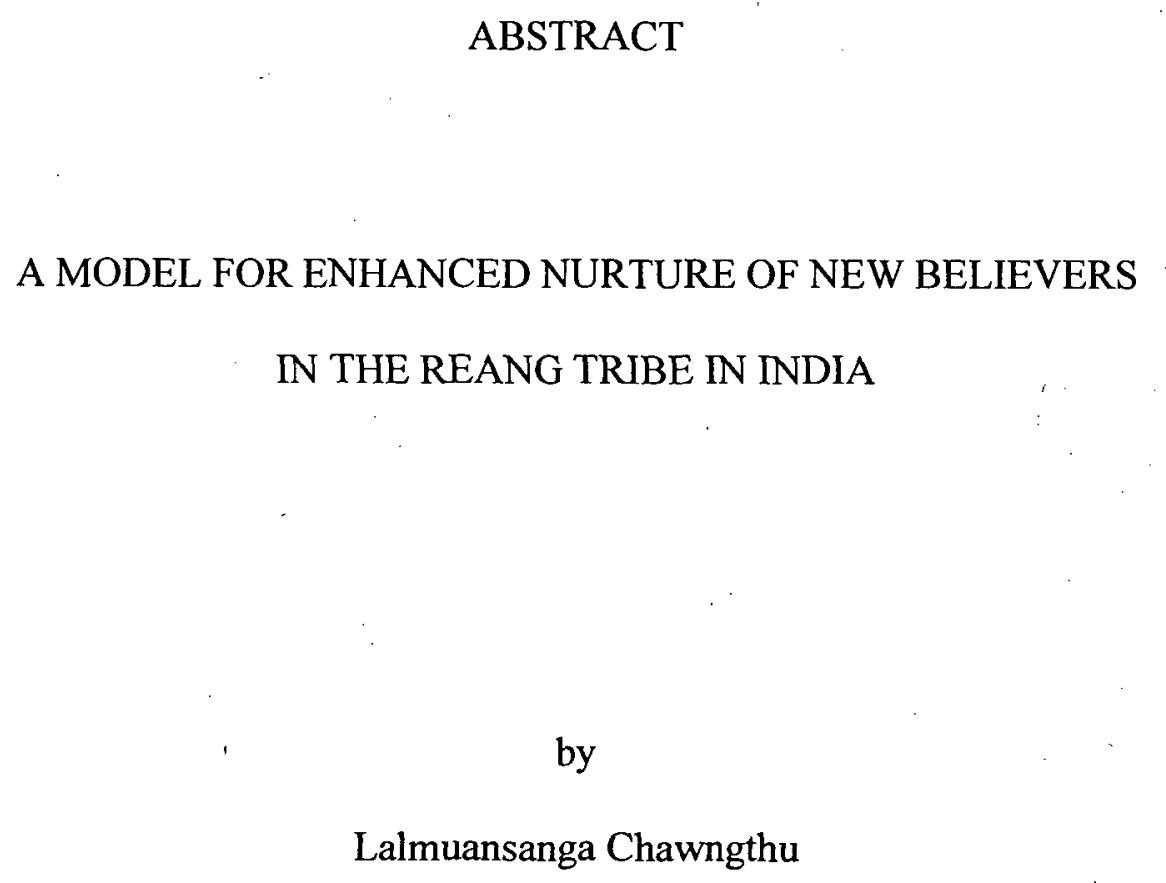

Lalmuansanga Chawngthu

Adviser: Gorden Doss 


\title{
ABSTRACT OF GRADUATE STUDENT RESEARCH
}

Dissertation

\author{
Andrews University
}

Seventh-day Adventist Theological Seminary

Title: A MODEL FOR ENHANCED NURTURE OF NEW BELIEVERS IN THE REANG TRIBE IN INDIA

Name of researcher: Lalmuansanga Chawngthu

Name and degree of faculty adviser: Gorden Doss, $\mathrm{PhD}$

Date of completed: May 2011

Problem

The Reang tribal people live in Tripura State, Northeast India. The Reang are largely illiterate and most live in poverty. Sicknesses and starvation are common among this tribal group. Although Adventists and other Christian groups have had reasonable success evangelizing the Reang, many converts appear to become Christians in search of the material aid they need. The Seventh-day Adventist Church needs a systematic and comprehensive plan of spiritual nurture for its Reang converts that will lead them into mature discipleship. 


\section{Method}

This study begins by developing a theological foundation for spiritual nurture based on selected biblical passages and the writings of Ellen White. A literature review outlines basic principles and methods of nurture. The cultural and religious context of the Reang is discussed to understand the setting for the project. Finally, a strategy for spiritual nurture among the Reang is developed.

\section{Results}

The project dissertation comprises a collection of researched materials and methods that can be used among Reang Adventists to lead them into a deeper, more mature life as disciples of Jesus Christ.

\section{Conclusion}

The implementation of the systematic, comprehensive training program outlined in this project has the potential to address the problem that this project seeks to address. New workers among the Reang can turn to this document as a helpful resource. 
Andrews University

Seventh-day Adventist Theological Seminary

\title{
A MODEL FOR ENHANCED NURTURE OF NEW BELIEVERS \\ IN THE REANG TRIBE IN INDIA
}

\author{
A Dissertation \\ Presented in Partial Fulfillment \\ of the Requirements for the Degree \\ Doctor of Ministry \\ by \\ Lalmuansanga Chawngthu
}

May 2011 
(C) Copyright by Lalmuansanga Chawngthu 2011 All Rights Reserved 


\title{
A MODEL FOR ENHANCED NURTURE OF NEW BELIEVERS \\ IN THE REANG TRIBE IN INDIA
}

\author{
A project dissertation \\ presented in partial fulfillment \\ of the requirements for the degree \\ Doctor of Ministry
}

\author{
by
}

Lalmuansanga Chawngthu

APPROVAL BY THE COMMITTEE:

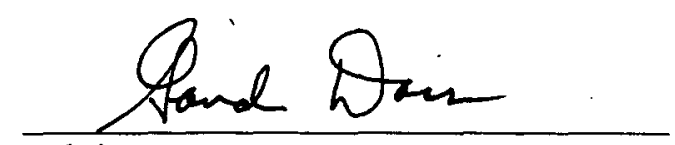

Adviser,

Gorden Doss

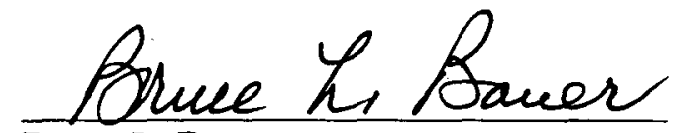

Bruce L. Bauer

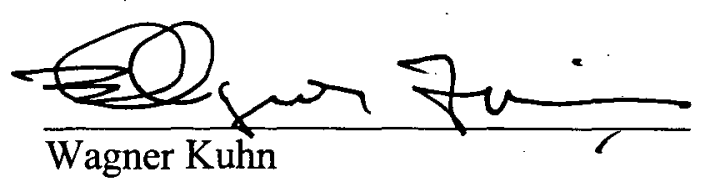

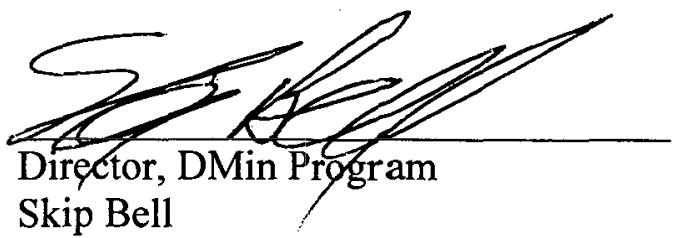

Denis Footin

Dean, SDA Theological Seminary

Denis Fortin

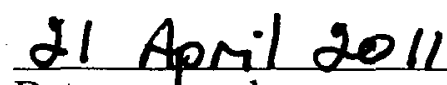

Date approved 


\section{TABLE OF CONTENTS}

LIST OF ILLUSTRATIONS $\ldots \ldots \ldots \ldots \ldots \ldots \ldots \ldots \ldots \ldots \ldots \ldots \ldots$

ACKNOWLEDGMENTS $\ldots \ldots \ldots \ldots \ldots \ldots \ldots \ldots \ldots \ldots \ldots \ldots \ldots$ vii

Chapter

1. INTRODUCTION $\ldots \ldots \ldots \ldots \ldots \ldots \ldots \ldots \ldots \ldots \ldots \ldots \ldots \ldots \ldots \ldots \ldots$

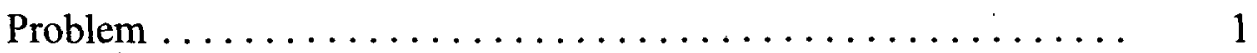

Justification of the Project . . . . . . . . 1

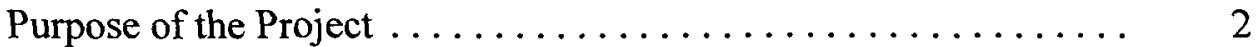

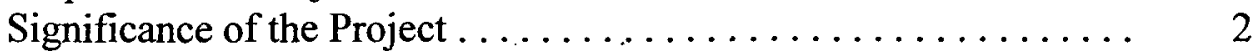

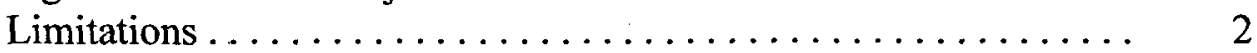

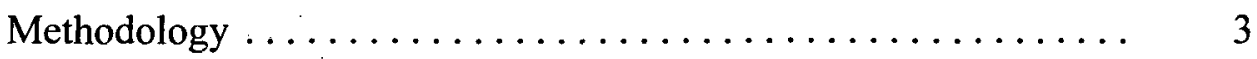

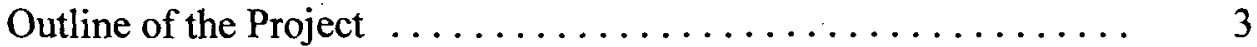

2. THEOLOGICAL FOUNDATION OF NURTURING $\ldots \ldots \ldots \ldots \ldots$

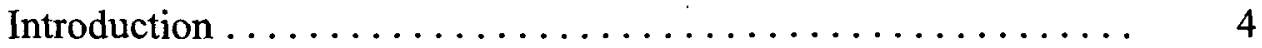

Definition of Christian Nurture $\ldots \ldots \ldots \ldots \ldots \ldots \ldots$

Nurturing in the Old Testament $\ldots \ldots \ldots \ldots \ldots \ldots \ldots \ldots \ldots$

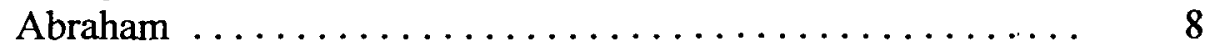

Moses .......................... 11

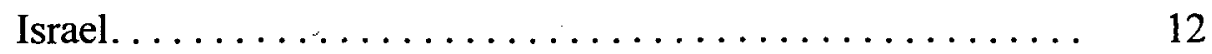

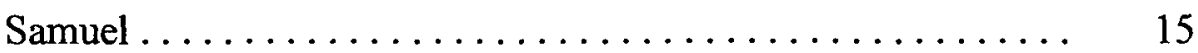

Jeremiah. . . . . . . . . . . . . . . . . . 16

Nurturing in the New Testament ............... 17

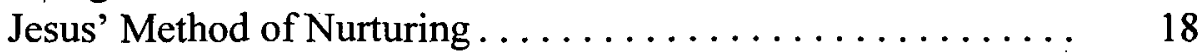

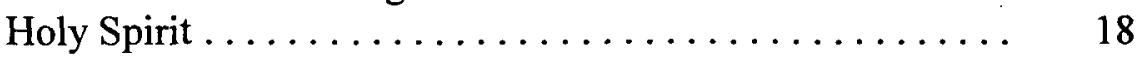

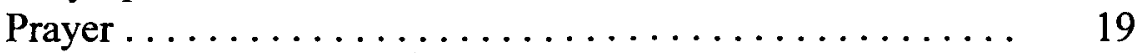

Lessons from Nature ................. 21

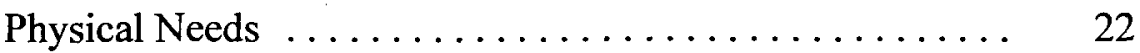

Jesus Stayed With the Disciples ............. 23

Training a Small Group .................. 23

Jerusalem Church....................... 24

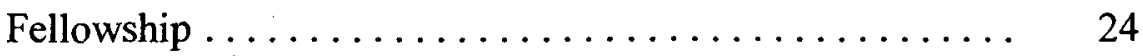

Believers Share Their Possessions. . . . . . . . . . 25

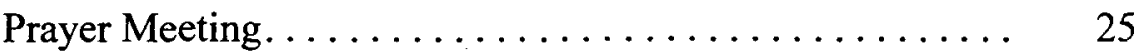

Witnessing ............................ 26 
Paul's Strategy of Nurturing New Believers . . . . . . . . 27

Church Visitation...................... 27

Letters......................... 28

Fellowship ........................ 28

Prayer........................... 29

Nurturing in the Spirit of Prophecy ................. 30

Follow Up ............................. 30

Teaching the Word of God................... 32

Visitation ............................ 33

Conclusion ............................. 34

3. LITERATURE REVIEW $\ldots \ldots \ldots \ldots \ldots \ldots \ldots \ldots \ldots \ldots \ldots \ldots \ldots \ldots$

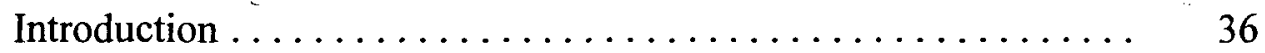

Nurture and Spiritual Formation $\ldots \ldots \ldots \ldots \ldots \ldots \ldots \ldots, 36$

Preaching and Nurturing $\ldots \ldots \ldots \ldots \ldots \ldots \ldots \ldots, \quad 40$

Sabbath School and Nurturing ................. 41

Prayer Meeting and Nurturing $\ldots \ldots \ldots \ldots \ldots \ldots \ldots \ldots, 41$

Small Groups and Nurturing $\ldots \ldots \ldots \ldots \ldots \ldots \ldots \ldots . \quad 42$

Discipleship Training ....................... 44

Nurturing and Commitment.................... 47

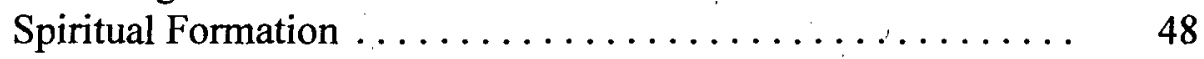

Spiritual Leadership $\ldots \ldots \ldots \ldots \ldots \ldots \ldots \ldots \ldots \ldots \ldots . \quad 50$

Conclusion........................... 53

4. CULTURAL AND RELIGIOUS CONTEXT $\ldots \ldots \ldots \ldots \ldots \ldots .54$

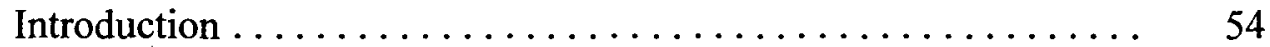

Historical-cultural Context $\ldots \ldots \ldots \ldots \ldots \ldots \ldots \ldots \ldots . \quad 56$

Reang Tribe Background $\ldots \ldots \ldots \ldots \ldots \ldots \ldots \ldots \ldots \ldots \ldots \ldots$

Reang Community ......................... $\quad 58$

Occupation ............................. 59

Marriage System ............................. 60

Culture and Value System ..................... 61

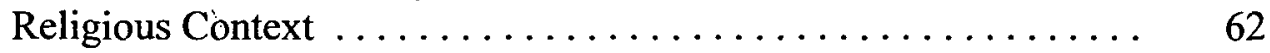

Religious Beliefs and Practices . . . . . . . . . . . . 62

Ceremony of Death ....................... 64

Impact of Christianity . . . .

Impact of Various Christian Denominations ............ 65

Seventh-day Adventist Approach to the Reang Tribe ........ 66

Needs and Objectives of the Mission for the Reang Tribe ....... 68

Challenges in Education and Occupation ............. 69

Difficulties With Indigenous Religious Practices ......... 70

Baptismal Growth and Decline . . . . . . . . . . . . . $\quad 71$

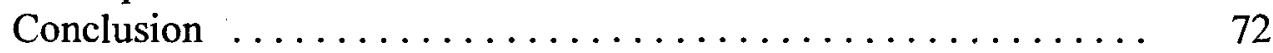




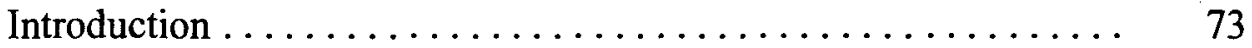

Spiritual Preparation Seminar for the Workers ............ 74

Devotional Life ........................... 75

Prayer and Meditation ....................... 76

Prayer Life and Meditation ................. $\quad 76$

Invitation of Prayer to Different Churches .......... 77

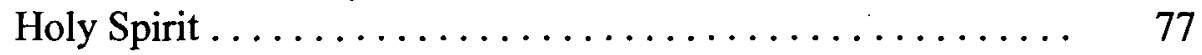

Preach With Power $\ldots \ldots \ldots \ldots \ldots \ldots \ldots \ldots \ldots . .78$

Commitment and Steadfastness $\ldots \ldots \ldots \ldots \ldots \ldots \ldots . \quad 80$

Discipleship .......................... 82

Follow Up to Nurture the Reang Believers . . . . . . . . . $\quad 84$

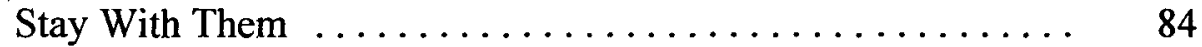

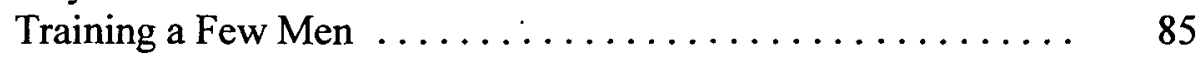

Choir Groups $\ldots \ldots \ldots \ldots \ldots \ldots \ldots \ldots \ldots \ldots \ldots \ldots \ldots \ldots \ldots \ldots \ldots \ldots$

Bible Study Classes . . . . . . . . . . . . . . . . . . . 86

Family Worship ........................ $\quad 87$

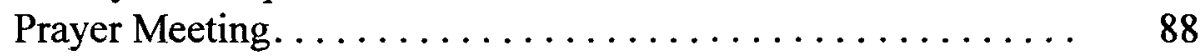

Visitation.............................. 89

House-to-House Visitation. . . . . . . . . . . . . . $\quad 89$

Church-to-Church Visitation . . . . . . . . . . . . . . 89

Adult Literacy Class. . . . . . . . . . . . . . . . . $\quad 89$

Translation of Spirit of Prophecy Books . . . . . . . . . . 90

Sabbath School........................... 90

Conclusion............................ 91

REFERENCE LIST $\ldots \ldots \ldots \ldots \ldots \ldots \ldots \ldots \ldots \ldots \ldots \ldots \ldots \ldots \ldots \ldots \ldots \ldots \ldots$

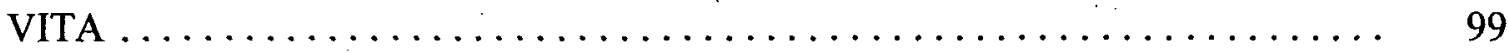




\section{LIST OF ILLUSTRATIONS}

1. India: States and Union Territories..................... 55

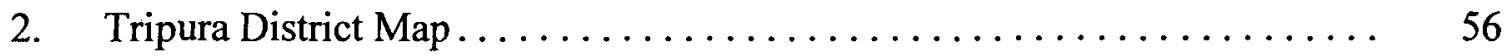




\section{ACKNOWLEDGMENTS}

A special appreciation to my wife Nutei, daughters Rintei and Maduhi, and son Mapuia who endured without the presence and support of a busy husband and father, especially during the time he was away from home in completing this project.

I am also grateful to a splendid host of friends and family members who encouraged me to undertake this further study. Mr. and Mrs. Vanrotluanga Vangchhia and Mr. and Mrs. Vanlalfela Colney provided a lovely home and helped our family in every way.

I thank my parents, Mr. and Mrs. Darkhuma Chawngthu, who raised me in a spiritual environment, and their continued prayer support throughout my study is the source of my success.

A special word of appreciation to the members of my committee: Dr.

Gordon Doss, Dr. Bruce Bauer, and Dr. Wagner Kuhn. Their genuine concern, care, and understanding of my personal obstacle, their constructive analysis, and their constant and consistent willingness to guide me are deeply appreciated.

There are many other prayers and willing hands that contributed to the completion of this Doctor of Ministry program. I thank my Lord for His grace, guidance, and comfort in grief and affirmation in triumph. 


\section{CHAPTER 1}

\section{INTRODUCTION}

The principles of spiritual nurturing are vital for bringing new believers to mature faith in Christ. Spiritual maturity cannot be neglected in all the churches that are established. Often so much energy is put into bringing new believers to Christ (praying for them, bringing them to evangelistic events, helping to answer their questions), that there is not much time left to nurture them. In a sense, they are left at the nursery. But when a person accepts Christ, the work of discipleship is only just beginning. The first few years are vital in establishing a new believer's walk with the Lord.

\section{Problem}

The Reang tribal people live in Tripura State, Northeast India. The Reang are largely illiterate and most live in poverty. Sicknesses and starvation are common among this tribal group. Although Adventists and other Christian groups have had reasonable success evangelizing the Reang, many converts appear to become Christians in search of the material aid they need. The Seventh-day Adventist Church needs a systematic and comprehensive plan of spiritual nurture for its Reang converts that will lead them into mature discipleship.

\section{Justification of the Project}

For the past decade the annual baptism rate has increased among the Reang tribe, 
but at the same time the retention rate has decreased. Thus, current nurturing methods need to be investigated.

An investigation of the current methods of nurturing among the Reang tribe is an important step in addressing the economic and spiritual life of the people.

\section{Purpose of the Project}

The purpose of this project is to develop a method of nurturing new believers of the Reang tribe in India. This project will strengthen the nurturing methodology of pastors and the missionary workers among the people and provide a lasting life of discipleship among the new believers. This project is designed to bring improvement in the area of my leadership role as a mentor to missionaries who are struggling to develop Seventh-day Adventist Christians among the Reang Tribe.

\section{Significance of the Project}

This project is designed to introduce a nurturing methodology to the Mizo Conference of the Seventh-day Adventist Church. This project should improve the spiritual life of the Reang tribe and bring relief to their daily survival struggle. Findings of this project will be shared with the local conference.

\section{Limitations}

One of the author's central concerns is that Adventist mission among the Reang be done in a wholistic way that addresses both spiritual and material needs. The limits of time and space regrettably made it impossible to include the broad topic of relief and development. 


\section{Methodology}

The study begins by developing a theological foundation for spiritual nurture based on selected biblical passages and the writings of Ellen White. A literature review outlines basic principles and methods of nurture. The cultural and religious context of the Reang is discussed to understand the setting for the project. Finally, a strategy for spiritual nurture among the Reang is developed.

\section{Outline of the Project}

Chapter 1 is the general introduction and overview of the project. It describes the problem, the justification, purpose, significance, limitations, methodology, and the outline of the project.

Chapter 2 contains a theological foundation of nurturing. It focuses on the biblical foundation of nurturing in the Old and the New Testaments and from the writings of Ellen G.'White.

Chapter 3 reviews literature on nurturing and the leadership role in the process of nurturing new converts.

Chapter 4 gives a brief overview of the Reang community, their cultural and religious background, and a historical review of the Adventist ministry among them. The impact of Christianity in their society is briefly mentioned.

Chapter 5 introduces a strategy to nurture the spiritual life of the new believers and suggests a necessary preparation for the workers to meet that strategy. 


\section{CHAPTER 2}

\section{THEOLOGICAL FOUNDATION OF NURTURING}

\section{Introduction}

God cares for his people and His marvelous interventions can be seen in various ways through His representatives during the Old and the New Testament times. Ellen G. White (1915) said,

In every period of this earth's history, God has had His men of opportunity, to whom He has said, "Ye are My witnesses." In every age there have been devout men, who gathered up the rays of light as they flashed upon their pathway, and who spoke to the people the words of God. Enoch, Noah, Moses, Daniel, and the long roll of patriarchs and prophets, ... these were ministers of righteousness. They were not infallible; they were weak, erring men; but the Lord wrought through them as they gave themselves to His service. (p. 13)

The concept of nurturing is biblical and God still has many people in modern times that are doing the nurturing work for Him just like during biblical times. White (1915) wrote that Christ is the head of the church after His ascension and continues His work in the world with His chosen ambassadors to minister to the needs of His children (p. 13).

God is active in nurturing His people and gives light to His representatives to show the path for His people. White (1915) says, "God empowers His representatives with light and guides their movement. If He did not they would not be able to provide any light. Ministers are the instrument of God and all the good things they accomplished is done through His power" (p. 14).

God remembers His children and always looks for people to do the nurturing 
work for those who have given their hearts to Him. The text, "Whom shall I send? And who will go for us?" (Isa 6:8) clearly reveals that God cares for His people.

\section{Definition of Christian Nurture}

Christian nurture is closely related with the principles and strategies in terms of shepherding, discipling, follow up, and spiritual formation. Van Rheenen defines nurturing as building up the body of Christ so that each part of the body supplies its gifts to the whole. It is the process of bringing individual Christians and the Christian community as a whole to maturity. It implies that new believers need encouragement in the process of their spiritual maturity. It helps new believers understand the battle against the devil and prepares them to stand against the powerful attack of Satan's temptations in the spiritual warfare (Van Rheenen, 1996, p. 2).

Hanks and Shell (1993) give a definition of follow up that could be related to nurturing. "Follow up is the spiritual work of grounding a new believer in the faith" (p. 110).

Steve Mills gives a further definition for follow up,

Follow-up is the spiritual ministry of grounding a new believer in the faith, which involves helping the new convert discover assurance of salvation and develop the basic disciplines and values critical to spiritual maturity. The goal is to help each believer become perfected in Christ (Mills, 2010, p. 45).

I understand nurturing as the processes of helping a believer to understand their need of Christ in order to grow in their faith into maturity and at the same time prepare the person to win others to Christ. The command of teaching (nurturing) in Matt 28:19, 20 includes the development of a new believer's growth. "Go ye therefore, and make disciples of all nations baptizing them in the name of the Father, and of the.Son, and of 
the Holy Ghost, teaching them to observe all things that I have commanded you." Hanks and Shell (1993) list five basic areas of spiritual truth which are essential for new believers:

1. Helping the new believer receive assurance of salvation and acceptance with God.

2. Helping the new believer develop a consistent devotional life.

3. Helping the new believer understand the basics of abundant Christian living.

4. Helping the new believer become integrated into the life of a local church.

5. Helping the new believer learn to share his faith with others. (p. 111)

Seventh-day Adventists would understand point number three to include an Adventist life style.

The Apostle Paul implies that new believers are like infants that need spiritual food to be mature in their spiritual life (Heb 5:13).. Nurturing is not endlessly teaching the new converts so that they are always on the receiving end (Heb 5:12). They must take their place along with other believers in building up the body of Christ. They must become mature Christians, mature in love and in taking their part in the corporate growth of the body of Christ (Eph 4:11-12). Converts are also to become stable in their faith and not carried away by every "wind of doctrine" (Eph 4:13-16).

Nurturing includes bringing new converts into fellowship with each other and with God. Individual conversion is not the exclusive goal of evangelism; fellowship helps the new believer's spiritual growth. The Apostle John wrote, "That which we have seen and heard we proclaim also to you, so that you may have fellowship with us and our fellowship is with the Father and with his Son Jesus Christ" (1 John 1:3).

\section{Nurturing in the Old Testament}

The working out of God's plan to bring all humanity to himself can be seen clearly from Genesis through Revelation. From beginning to end, Scripture describes a 
remarkable plan: God intends to dwell in men and women and to draw all to Himself. From Adam and Eve hiding in the bushes to John envisioning a new heaven and a new earth, God's intent has been to bring light and salvation to those who are perishing. "I will also give you as a light to the Gentiles, that you should be my salvation to the ends of the earth" (Isa 49:6).

God has been doing the work of nurturing for the entire human race. When believers do the work of nurturing, they are merely participating in what God has been doing in the life of every individual for thousands of years. Coleman (1987) says that believers are merely the channel through which the Spirit of Christ makes disciples (p. 155). God has a plan for each individual and sees every detail of that person's life. "Your eyes saw my substance, being yet unformed. And in your book they all were written, the days fashioned for me, when as yet there were none of them" (Ps 139:16). Nurturing Christians are to convince and make people aware that God has a plan for each individual. "For I know the plans I have for you," declares the Lord, "plans to prosper you and not to harm you, plans to give you hope and a future" (Jer 29:11).

The promise of God also reveals the true nature of God and His concept of nurturing toward His people. "Have I not commanded you? Be strong and courageous. Do not be terrified; do not be discouraged, for the Lord your God will be with you wherever you go" (Josh 1:9).

The writing of the Psalmist declared that the nature of God can be related to the nurturing process, "Though he falls, he shall not be utterly cast down; For the Lord upholds him with His hand (Ps 37: 34).

Blessed is he who considers the poor; The Lord will deliver him in time of trouble. The Lord will preserve him and keep him alive, and he will be blessed on the earth; 
you will not deliver him to the will of his enemies. The Lord will strengthen him on his bed of illness; you will sustain him on his sick bed. (Ps 41:1-3)

"Whō keeps our soul among the living, and does not allow our feet to be moved [slip] (Ps 66:9). If I say, “"My foot slips,' Your mercy, O Lord, will hold me up.” (Ps 94:28). "My flesh and my heart fail; but God is the strength of my heart and my portion forever" (Ps 73:26).

God is ready to give His power to the weak and those who need strength.

He gives power to the weak, and to those who have no might He increases strength. Even the youth shall faint and be weary, and the young men shall utterly fall, but those who wait on the Lord shall renew their strength; they shall mount up with wings like eagles, they shall run and not be weary, they shall walk and not faint. (Isa 40:2931).

God wants to chase away every fear and stumbling block and give people courage for their growth and development, "Fear not, for I am with you; be not dismayed, for I am your God. I will strengthen you, yes, I will help you, I will uphold you with my righteous right hand" (Isa 41:10).

God also wants to take charge in all areas of our life and to be our comfort in every stage of life, "Ėven to your old age, I am He, and even to gray hairs I will carry you, I have made, and I will bear; even I will carry, and will deliver you" (Isa 46:4).

God suffers when His people suffer because He is a loving God and has pity on His people; "In all their affliction He was afflicted, and the Angel of His Presence saved them; In His love and in His pity He redeemed them; and He bore them and carried them all the days of old" (Isa 63: 9).

\section{Abraham}

God's intervention in the life of Abraham clearly displays God's attitude of 
nurturing and His intention to bless all humanity. God related to Abraham His plan. Abraham lived in Haran but God's plan was for him to move to Canaan. God said, "I will make you a great nation; I will bless you and make your name great; and you shall be a blessing ... and in you all the families of the earth shall be blessed" (Gen 12:2-3).

Abraham practiced nurturing by maintaining a well disciplined environment for his family and guided his household in the way of the Lord. "For I have chosen him, so that he will direct his children and his household after him to keep the way of the Lord by doing what is right and just, so that the Lord will bring about for Abraham what he has promised" (Gen 18:19). Abraham erected an altar and offered a sacrifice to the heavenly God, and silently protested against the idolatry around him. He introduced the people in his surrounding area to a more perfect knowledge of God. The sacrifice confirmed Abraham's belief in the death of the Son of God as an atonement for $\sin$ (Nichol 1978, 1: 297).

Abraham had daily communion with God for his spiritual growth and for his household. He built an altar in various places and called on the name of the Lord. White (1958) says, "Like Abraham, those who profess to love God should erect an altar to the Lord wherever they pitch their tent; in this crucial time every house should be a house of prayer" (p. 144).

Abraham was faithful in witnessing the Word of the Lord and could be known as a true disciple of Christ. Abraham was the "world's first foreign missionary" who erected an altar wherever he pitched his tent (Nichol 1978, 1:297). And there he built an altar to the Lord, who had appeared to him (Gen $12: 7 ; 13: 18$ ). The public worship that was offered for the members of his household and for pagans living nearby had an impression 
upon them. Many people often hesitate to reveal their faith publicly but not Abraham, wherever he went he confessed the One whom he trusted and obeyed (p. 297). Abraham did not neglect his family worship and nurtured his family by building an altar in the midst of paganism.

Abraham maintained a well-disciplined environment in his household. White (1958) says that Abraham commanded his household and did not give only right instruction, but maintained the authority of just and righteous laws. He would not allow any mistaken affection and sinful desire to develop in his household and protected his children from such an environment (p. 142).

White (1958) continues to say,

Abraham's household comprised more than a thousand souls. Those who were led by his teachings to worship the one God, found a home in his encampment; and here, as in a school, they received such instruction as would prepare them to be representatives of the true faith. Thus a great responsibility rested upon him. He was training heads of families, and his methods of government would be carried out in the households over which they should preside. (p. 141)

Abraham modeled the role of discipleship. He did not merely try to impart knowledge of God to his household but he also prepared them to convey the same knowledge to the world. White (1958) explains how Abraham built up affection toward his children and his household that led him to guard their religious faith, to impart to them knowledge of the divine statutes. He transmitted the most precious legacy to them and through them to the world. All were taught that they were under the rule of the God of heaven. His own example, the silent influence of his daily life, was a constant lesson. He did not neglect the soul of the humblest servant. In his household there was not one law for the master and another for the servant; a royal way for the rich and another for the 
poor. All were treated with justice and compassion, as inheritors with him of the grace of life (p. 142).

Abraham imparted the true role of discipleship to Isaac and nurtured him to be able to stand the hardest trial of discipleship, submission of life to God. White (1958) says,

Isaac had been trained from childhood to ready, trusting obedience, and as the purpose of God was opened before him, he yielded a willing submission. He was a sharer in Abraham's faith, and he felt that he was honored in being called to give his life as an offering to God. He tenderly seeks to lighten the father's grief, and encourages his nerveless hands to bind the cords that confine him to the altar (p. 152).

\section{Moses}

In the life of Moses we can see the importance of childhood nurturing. Moses' mother played an important role in nurturing the mind and character of her son which enabled him to become the future leader of the Israelites. White (1958) mentions the importance of the mother's influences for the destiny of their children,

How far-reaching in its results was the influence of that one Hebrew woman, and she an exile and a slave! The whole future life of Moses, the great mission which he fulfilled as the leader of Israel, testifies to the importance of the work of the Christian mother. There is no other work that can equal this. To a very great extent the mother holds in her own hands the destiny of her children. She is dealing with developing minds and characters, working not alone for time, but for eternity. (p. 244)

Both parents have a responsibility to help shape the growth of their children, but the environment also has an impact in how their lives and characters are formed by their surroundings and the communication they have with others. White (1958) says Moses had learned many things that he would have to relearn. The influences of the Egyptian palace had left deep impressions upon his developing mind and had molded some of his habits and character. God wanted to remove all those impressions and so put him in a 
different environment. Moses needed to struggle to renounce error and accept truth, but God would be his helper when the conflict should be too severe for human strength (p. 248). God cannot do His work in a person's life until he or she understands they cannot do anything apart from Him. God nurtured Moses during his 40 years with the sheep. Wicker (1944) says, "God took forty years to teach Moses to be somebody and teach him that he was nobody" (p. 37).

God also nurtured Moses during the 40 years he led Israel. God's promise to Moses reveals the true nature of God. He promised to be with him. God is the one who actually did the leading but He gave the privilege to Moses; he used a humble shepherd and his rod to lead the Israelites from the Egyptian army. "I will certainly be with you. And this shall be a sign to you that I have sent you: When you have brought the people out of Egypt, you shall serve God on this mountain" (Exod 3:12). God did not hand over responsibility to Moses without promising to be with him. God was doing His work through the life of Moses to lead His chosen people to Canaan. Rylaarsdam (1980) says that Moses was informed that this was God's project, he was only a unit in his work, and God was at the center of it (p. 874).

Israel

God worked to do His mission through His chosen people and used various ways to nurture them. God depicted his people as a vineyard "What more could have been done for my vineyard than I have done for it?" (Isa 5:4).

God does not neglect His people but loves everyone and is willing to give of the best for their future. God plays the role of a Vinedresser who always devotedly tends His vineyard (Isa 5:1-7), a Physician who tenderly nurses His patients (Jer 8:22), and a Parent 
who lovingly teaches His child to walk (Hos 11:1, 3). These prophetic metaphors reveal God's desire to personally relate to Israel, is chosen people. God is portrayed in Scripture as the ever-present, compassionate Lord sending His messengers to nurture His people to come into a relationship with Him. God used His prophets to nurture His chosen people and constantly conveyed His messages through visions and dreams to give the plan and guidance for His people.

The experience of Israel helps people to understand God is active in leading His people and preparing their way ahead of them. His leading is active 24 hours a day, seven day a week; it is appropriate to say God is always ready and active to lead His people. "And the Lord went before them by day in a pillar of cloud to lead the way, and by night in a pillar of fire to give them light, so as to go by day and night" (Exod 13:21).

God is concerned for the physical needs of His people, "For they drank of that spiritual Rock that followed them and that Rock was Christ" (Num 20:11; 1 Cor 10:4). Honeycutt (1969) illustrates God as the source of living water, and relates this theme to the New Testament where Jesus says he gives the water of life (John 4:10). "God never abandons his people, but grants to them life-giving water, The Lord is among his people" (p. 401).

God miraculously sent food to the Israelites during their forty year sojourn in the desert (Exod 16; Num 11:6-9). Manna fell during the night in small white flakes or grains which covered the ground and gave the appearance of hoar frost. These grains are described as resembling coriander seed and bdellium, with a taste like "flour with honey" or "bread tempered with oil" (Exod 16:31; Num 11:7-8). Later God sent meat to the people. "So it was that quail came up at evening and covered the camp, and in the 
morning the dew lay all around the camp" (Exod 16:13). Oswalt (2008) says God's intervention in His creation reveals His ability to bless His people in extraordinary ways. He revealed His caring nature in ways that were meant to be unforgettable. God could have dropped excesses of food without giving them any restriction. But God remembered that when humans are self sufficient, they easily forget their relationship with God who shapes human characters (p. 408). An illustration of Oswalt (2008) helps people to understand that God is mindful of every detail human life as it forms the spiritual life (p.259-558). Honeycutt (1969) cites this incident as a spiritual lesson, "He supplies His people with food, cares for them in their needs, and He makes the food which He gives them the vehicle of spiritual lessons" (p. 398).

God's original intention was to have close communion with human beings. This was the plan He attempted to carry in the Garden of Eden in order to nurture the physical, mental, and spiritual growth of the human being. But sin thwarted the original plan of God and he brought out another plan whereby He might be reunited with His people. God said to Moses, "And let them make me a sanctuary that I may dwell among them" (Exod 25:8). Andreasen (1937) suggests that the earthly sanctuary was a special place where God dwelt among His chosen people as their Savior and Leader, and was the most sacred place on earth (p. 10).

Daily food is needed for physical growth and the same thing implies to spiritual growth. Andreasen (1937) says that the daily service in the sanctuary symbolized and signified human's need of God, and also God's complete provision for supplying that need (p. 164).

God displayed through the sacrificial system the condition of humanity and 
human being's need of God for salvation. God wanted to teach Israel through the sacrificial system the way of salvation which is the process of Christian nurturing. Again Andreasen (1937) says that God wanted to teach them through the sacrificial system that sin means death and the forgiveness of sin can be obtained only through confession and the ministration of blood (p. 23, 24).

\section{Samuel}

The life of Samuel illustrates the importance of childhood nurturing in the Old Testament. Prayer for the child even before they are conceived is very important for the mother and especially for the future of the child. Samuel was the result of his mother's prayer. "Perhaps God waited long" for her to surrender herself to Him. "He could have opened her womb before, but was she ready to bear the responsibility?" (Nichol 1978, 2:455). Hannah prayed to the Lord, "O Lord of hosts, if You will indeed look on the affliction of Your maidservant and remember me, and not forget Your maidservant, but will give Your maidservant a male child then I will give him to the Lord all the days of his life, and no razor shall come upon his head" (1 Sam 1:11). Hannah began her nurturing work before conceiving her son and wanted her son to be a servant of God. Hannah in pronouncing that "no razor shall come upon his head" is an indication that she was assigning a Nazarite vow to her anticipated son (Num 6:2).

Hannah remembered the importance of training the child and gave up some of her religious activities to have more time to train her son. "But Hannah did not go up, for she said to her husband, "Not until the child is weaned; then I will take him that he may appear before the Lord" (1 Sam 1:22).

Samuel was looked upon by his mother not merely as a child but as an offering to 
God. Therefore she sought to have him trained for God from his earliest infancy; she ministered to his physical needs with much care and prayer, directing his thoughts toward the Lord of hosts from very earliest age (Nichol 1978, 2:456).

White (1958) describes how Hannah taught her son to be a minister of the Lord and how her daily prayers contributed to Samuel's success in ministry.

From Shiloh, Hannah quietly returned to her home at Ramah, leaving the child Samuel to be trained for service in the house of God, under the instruction of the high priest. From the earliest dawn of intellect she had taught her son to love and reverence God and to regard himself as the Lord's. By every familiar object surrounding him she had sought to lead his thoughts up to the Creator. When separated from her child, the faithful mother's solicitude did not cease. Every day he was the subject of her prayers. Every year she made, with her own hands, a robe of service for him; and as she went up with her husband to worship at Shiloh, she gave the child this reminder of her love. Every fiber of the little garment had been woven with a prayer that he might be pure, noble, and true. She did not ask for her son worldly greatness, but she earnestly pleaded that he might attain that greatness which Heaven values--that he might honor God and bless his fellow men (p. 572).

The Bible says, "And the child Samuel grew in stature and in favor both with the Lord, and also with men" (1 Sam 2:26). White (1958) helps us understand how Hannah's prayers and careful teaching prepared Samuel to be faithful even in the midst of evil practices. "Samuel was not free from evil influence or sinful examples even though he was brought up in the tabernacle. The sons of Eli did all kinds of evil but Samuel did not follow their evil ways, it was his constant endeavor to become what God expected him to be" (p. 573).

\section{Jeremiah}

The vision of Jeremiah portrays God's role in nurturing Israel. God said to him, "O house of Israel, cannot I do with you as this potter? saith the LORD. Behold, as the clay is in the potter's hand, so are ye in mine hand, O house of Israel" (Jer 18:1-6). God likens Himself to a potter and Israel as the clay upon the potter's wheel. God depicts 
himself as the potter, humanity is the thing fashioned, human beings are the clay. If we examine these illustrations and apply them to God's creative work, we begin to get a clearer picture in our mind regarding how God has created us and nurtured our life. God is the one who bring changes in our life and we cannot change our life nor the life of others. "Can the Ethiopian change his skin or the leopard its spots? Then may you also do good who are accustomed to do evil" (Jer 3:23). This text suggests the attitude we need to have in the nurturing work'

Nee (1996) supported the above text and explained the working of God in a person's life, "God is working in us all the time. He is continually expending much effort upon us so that we may be white, and He is continually laboring upon us to make us shining; His desire is for us to be bright" (p. 113).

God loves His people with an unending love and always tries to draw them closer to him, "Yes, I have loved you with an everlasting love; therefore with loving kindness I have drawn you" (Jer 31: 3).

The Old Testament confirms that nurturing comes from the heart of God and it is clearly seen in the life of Abraham, Moses, Israel, Samuel, Jeremiah, and others. God is longing to spend more time with His people; He wants them to be spiritually mature and experience true happiness in their relationship with Him.

\section{Nurturing in the New Testament}

The central act of God nurturing His creatures happened when He sent His son to earth (Heb 1:1,2). The life of Jesus Christ and his method of ministry has given a true model of nurturing. Various examples of nurturing can also be seen from the first century church. The apostle Paul also played an important role in shaping the early churches and 
left examples of various methods of nurturing in his ministry.

\section{Jesus' Method of Nurturing}

Jesus, the Creator of the universe and the one who knows every detail of the human life, has shown a model of nurturing in His ministry. The writings of Paul clearly mention how Jesus loved the church and showed his attitude of nurturing toward His children.

Husbands, love your wives even as Christ also love the church and gave Himself up for her, that He might sanctify and cleanse her with the washing of water by the word, that He might present her to Himself a glorious church not having spot or wrinkle or any such thing, but that she should be holy and without blemish." (Eph 5:25-27)

The life of Jesus Christ and His ministry reveals the role of nurturing and the responsibilities of discipleship that applies to every church member.

Jesus was indeed a disciple-gathering teacher. He used every opportunity to call, train, educate, and nurture disciples. He was never too busy to help a needy soul. Disciple training was at the center of His ministry. We believe and strongly suggest that just as the tasks of disciple-making, teaching, training, and nurturing were central to Jesus' ministry, they also must be central to the mission of every member and every church in the twenty first century. This task is not limited to pastors, Bible workers, elders, deacons, and church officers. It is the task of every member, for Jesus' commission excluded no disciple. "Go ye" includes you. (Melbourne, 2007, p. 121)

\section{Holy Spirit}

The interaction of the Holy Spirit in the life of Jesus Christ informs us of the importance of the Holy Spirit in every aspect of life and ministry. As in the physical realm, a new Christian needs a spiritual parent to have a healthy birth in their spiritual life. Mary was filled with the Holy Spirit even before she conceived Jesus, "The Holy Spirit will come upon you, and the power of the Most High will over shadow you" (Luke $1: 35)$. 
The Bible describes the new believer as a spiritual baby, "Like newborn babies, crave pure spiritual milk, so that by it you may grow up in your salvation" (1 Pet 2:2). Hanks and Shell (1993) write, "A new believer needs spiritual parents who will watch over them and provide their spiritual needs in their early stage of their growth" (p. 111). Coleman (1997) also says, "All children of God start as newborn babies in Christ, they need parental care to grow up in their faith" (p. 110).

The Bible tells us that Jesus was anointed and filled with Holy Spirit before he started His ministry. "The spirit of the Lord is on me, because he has anointed me to preach good news to the poor" (Luke 4:18).

The Holy Spirit also controlled the movement of Jesus Christ in His ministry, "Jesus full of the Holy Spirit returned from the Jordan and was led by the Spirit in the desert" (Luke 4:1). The power of the Holy Spirit and the impact of the Spirit can be seen in the ministry of Jesus Christ and the people He ministered to. "Jesus returned to Galilee in the power of the Spirit and news about Him spread through the whole countryside. He taught in their synagogues, and everyone praised Him" (Luke 4:14). If Jesus needed the anointing of the Holy Spirit before He ministered to people to meet their needs how much more do we need this blessed anointing. The surest way to receive this blessing is to pray and ask God for it.

\section{Prayer}

Prayer was an important part of Jesus' ministry. Many times in the Gospels, one can read that Jesus prayed or went alone to pray apart from the disciples. Jesus prayed for Himself and His disciples and for all the believers (John 17). He prayed for the protection 
of all the believers from evil. Jesus deeply cares about the spiritual maturity of His children.

The practice of His devotion in His own life was observed by His disciples as one day they were asking to learn His secret. "One day Jesus was praying in a certain place. When He finished, one of His disciples said to him, 'Lord, teach us to pray, just as John taught His disciples"' (Luke 11:1). Pentecost (1996) mentions the impact of Jesus' prayer on His disciples: "The intimate relationship which existed between the Lord Jesus Christ and His Father during the days of His earthly life brought a deep conviction to the hearts of the disciples" (p. 77). Coleman (1997) says that as soon as they are able to pray on their own, He continue to teach them more about communion and depending upon God for a daily supply of grace (p. 157). Jesus strengthened His disciple's growth by showing the way of communication to God.

Jesus often prayed alone in nature to strengthen His communion with God. "Jesus often withdrew to lonely places and prayed" (Luke 5:16). Jesus showed the significance of praying alone in nature. The Bible says, "One of those days Jesus went out to a mountainside to pray and spent the night praying to God" (Luke 6:12). Jesus often spent the night in prayer, showing how important prayer was if one wanted to understand the directions from God.

Jesus taught His disciples to be persistence in their prayer, "Then Jesus told his disciples a parable to show them that they should always pray and not give up" (Luke 18:1). Jesus knew that not all his prayers would be answered as expected, especially when he cried out to God the Father from Gethsemane. Three times Jesus prayed for God to allow an easier path, "Yet not as I will, but as You will" (Matt 26:39). Thus, Jesus 
showed the correct attitude needed in prayer to His disciples and revealed to them that it is God who is in charge. The prayer of Jesus reveals the necessity of prayer in the life of the disciples and new believers in Christ in order to have successful growth in their spiritual life.

Armstrong (1983) mentions how Jesus taught prayer to His disciples, "Christ had taught them to pray by word and by example. They had seen him pray at his baptism, in the wilderness, on the mountain, alone, in a group, all night, at his transfiguration, the last night before His death, and while dying on the cross" (p. 44; Luke 3:21; 5:16; 6:12; 9:18, $29 ; 11: 2 ; 22: 41 ; 23: 46)$.

\section{Lessons from Nature}

Jesus taught lessons from the very nature which he had made, "See how the lilies of the field grow. They do not labor or spin. Yet I tell you that not even Solomon in all his splendor was dressed like one of these. If that is how God clothes the grass of the field, which is here today and tomorrow is thrown into fire, will he not much more clothe you?" (Matt 6:28-30). White (1941) says, "Christ taught from the things His own hand had made and which had qualities and powers that He himself had imparted" (p. 18).

Christ imparted the knowledge of God to His disciples and His listeners from nature. His teaching of the parables from nature can be seen in the parable of the sower, the parable of weeds, the parable of the mustard seed and the yeast, the parable of the hidden treasure, and the pearl (Matt 13). White.(1941) says that we are to become acquainted with the Creator through nature, "The book of nature is a great lesson book, which in connection with the Scripture we are to use in teaching others of His character, and guiding lost sheep back to the fold of God" (p. 24). 


\section{Physical Needs}

Jesus did not neglect the needs of His children and he came to meet all our needs: physical, mental, and spiritual. "The spirit of the Lord is on me, because he has anointed me to preach good news to the poor. He has sent me to proclaim freedom for the prisoners and recovery of sight for the blind, to release the oppressed, to proclaim the year of the Lord's favor" (Luke 4:18-19). White (1941) says that when Christ healed the sick He often laid His hand on them and came into close contact with those seeking help (p. 418).

Jesus is compassionate and $\mathrm{He}$ cares for His people. Jesus came and saw the needs of the people. He met the physical need of hunger for bread (John 6:1-14); he also met the spiritual hunger for the bread of life (John6:48). Jesus is the living example of the Word, "The Word was made flesh and lived among us" (John 1:14).

Jesus healed all manner of sickness and disease. The people followed him because he could help them. He became famous as a healer. The Bible says, "Jesus went throughout Galilee, teaching in their synagogue, preaching the good news of the Kingdom, and healing every disease and sickness among the people. News about him. spread all over Syria, and people brought to him all who were ill with various diseases, those suffering severe pain, the demon-possessed, those having seizures, and the paralyzed, and he healed them" (Matt 4:23-24). White (1940a) says that through His servant, God designed that the sick, the unfortunate, those possessed of evil spirits, shall hear His voice, and his desire is to be the comforter through human agencies (p. 350). 


\section{Jesus Stayed with the Disciples}

The Bible tells that Jesus chose twelve men to be "with him" (Matt 3:14). Adsit (1988) relates Jesus' relationship with His disciples as a powerful means of nurturing and building up their future ministry. "Jesus showed us the powerful influence of relationship building. For many years the twelve disciples were Jesus' constant companions, observing His life in a wide variety of contexts" (p. 56). Hanks and Shell (1993) also mentioned the relationship of Jesus with His disciples: "Having called His men, Jesus spent most of His time with them. This was the essence of His training. His disciples were distinguished, not by outward conformity to certain rituals, but by being with Him. Knowledge was communicated through the living personality of One who walked among them not in terms of laws and dogmas" (p. 55).

\section{Training a Small Group}

The ministry of Jesus was primarily a ministry of discipling. He spent the majority of His time with the twelve apostles. His goal, in a sense, was to pour Himself into their lives, to show them His ways, so that when He returned to heaven they would continue His ministry on earth. His disciples became His feet, hands, and mouth after $\mathrm{He}$ was gone. Hanks and Shell (1993) say, "Jesus showed His disciples how to minister. Great preaching and teaching hold an important place but they cannot replace the apprenticing concept demonstrated by Christ" (p.24). Jesus prepared His disciples to be vessels of His power and presence. Jesus not only made disciples; He made disciplemakers. His "great commission" was to go and make disciples. Coleman (1997) says, "His strategy was to prepare a nucleus of laborers for the harvest. These followers in turn would reach others and train them with the same vision" (p. 13). Jesus envisioned the day 
when His gospel would be heard by "the whole world" (Matt 24:14). Coleman (1997) writes that the process of winning persons is completed only when its continuation is assured. As they reproduce their kind through the Holy Spirit and teach those they win to reach others, eventually the world will be reached with the Gospel (p. 158).

The commission Jesus gave to the disciples on the Galilean mountain prior to His ascension is four dimensional. The disciples were instructed to go, make disciples, baptize, and teach. This suggests that discipleship cannot be static or sedentary. The gospel must be taken from place to place. Discipleship involves going where people are to take the gospel to them (Matt 28:19,20).

\section{Jerusalem Church}

The Jerusalem Church faithfully continued the mission of Jesus Christ. Lawless (2002) says that "the early church took seriously Jesus' mandate to obey His teachings and to teach others to obey. Conversion, followed by baptism, was followed by teaching that demanded obedience" (p. 47). The first century church left some significant lessons that can be applied to the 21 st century church.

\section{Fellowship}

The strength of the Jerusalem church was their dedication to the teaching of the apostles and the fellowship they had regularly. The Bible says, "And they continued steadfastly in the apostle's doctrine and fellowship, in the breaking of bread and in prayers. So continuing daily with one accord in the temple and they ate their food with gladness and simplicity of heart" (Acts 2:42, 46). Coleman (1987) agreed and said that the unity and their fellowship resulted in the outpouring of the Holy Spirit. "They came to 
this oneness of mind in the meeting preceding Pentecost would indicate that unity provides a fertile soil for the Spirit of God to work" (p. 61). Kreider (2007) says, "The Early Church followed the disciples' example of spiritual parenting by meeting house to house to experience family life to its fullest" (p. 118).

\section{Believers Share Their Possessions}

The Jerusalem church practice of mutual support had a deep impact on the growth of the new believers. Coleman (1987) says that the willingness to bear one another's burden can be seen in their care of the physical needs of others. They were like family and each person felt the responsibility for the others (p. 64). The Bible says, "Now all who believed were together, and had all things in common, and sold their possessions and goods and divided them among all, as anyone had needed" (Acts 2:44, 45). There were no needy persons among them because from time to time those who owned the land sold their land and brought them to the apostles for distribution to the poor (Act 4: 34). Martens and Swartley (1993) describe that the unity of the early church resulted in sharing their possessions.

The members of the church are of one heart and soul because all are centered on Jesus, who unifies deep within. Thus dedicated to Christ and one another, no one claims private ownership of any possessions. All things belong to the Lord and are on loan to them for the good of the community. (p. 68)

\section{Prayer Meeting}

In the Jerusalem church, the importance of Christians praying with one another for their spiritual growth and evangelistic growth can readily be seen. They all joined together constantly in prayer, "These all continued with one accord in prayer" (Acts 1:14). Armstrong (1983) emphasizes this and says that the members of the first church 
were people of prayer, they all prayed together, so it is not surprising that great things happened. If every church member were actively involved in prayer great things would happen in the church now (p. 43). The Jerusalem church prayed for wisdom to make right decisions, "You, O Lord, who know the hearts of all, show which of these two You have chosen" (Acts 1:24). The first church taught all the new converts how to pray (Acts 2:42). The Jews informed the church to keep silent about Jesus but they prayed for boldness and they were filled with the Holy Spirit. They went out and spoke the message boldly (Acts $4: 29-31)$.

\section{Witnessing}

The early believers in the Jerusalem Church acknowledged that they were Christ's witnesses and their witness helped the growth of individuals and the growth of the church. Armstrong (1983) wrote, "Every believer needs the personal joy of helping another to receive Christ. Every believer needs [to do] some teaching in order to be a strong witness" (p. 62). The new converts were taught to witness in the Jerusalem church and the Lord added to their numbers daily those who were being saved (Acts 2: 42, 47).

The Bible suggests that all the believers in the Jerusalem church were witnesses. "This Jesus God has raised up, of which we are all witnesses. We are His witnesses to these things" (Acts 2:32; 5:32). All the early believers witnessed in the Jerusalem church. The Scripture says that "those who were scattered went everywhere preaching the word" (Acts 8:4). Armstrong (1983) says that the Greek word used for preaching is the same word used for evangelism and gospel. They all went evangelizing (p. 60). 


\section{Paul's Strategy of Nurturing New Believers}

Apostle Paul demonstrated the significance of strategy and an attitude of nurturing in his ministry with the new believers. Barna (2001) says, "Nobody imitated Jesus' model better than Paul did. And Paul's imitation of Christ is incredibly significant because he shows all that it can be done. After being saved and then discipled, he launched into a time of powerful, effective ministry" (p. 25).

God wants all people to become more and more like Christ. Paul showed that he deeply cared for new believers and their spiritual growth. "My little children for whom I labor in birth again until Christ is formed in you" (Gal 4:19). "But we were gentle among you, even as a nurse cherished her children. Spiritual babies, like other newborns, need gentleness and nourishment, So being affectionately desirous of you, we were willing to have imparted unto you, not the gospel of God only, but also our own souls; because you were dear unto us" (1 Thess 2:7,8).

Paul described his role as a father and a mother who encourages and comforts the believers, "As ye know how we exhorted and comforted and charged every one of you, as a father does his children" (1 Thess 2:11). "We were gentle among you, just as a nursing mother cherishes her own children" (1 Thess 2:7).

\section{Church Visitation}

Paul's epistles indicate his strong desire to return to each of the churches he had established. In some cases this was possible (Acts 16:3) but in others it was not. Barna (2001) says that the apostle Paul did not merely journey back and forth between the churches he established (p. 24). In some instances Paul sent other men, such as Timothy, to check on the progress of the church (1 Cor 4:17; Acts 19:22). Coleman (1987) says that Paul learned many lessons from the fellowship he had with the disciples in Damascus 
and made it a policy to stay and work with new disciples. He understood the importance of personal follow up to meet the new believer's spiritual needs (p. 72).

\section{Letters}

Paul also wrote letters in order to nurture the new believers and to correct the problems of the church. Ball (1996) says that the writing of Paul set forth the foundational truths of the Christian faith and when false teachers came to Rome, the believers there would be fortified with a strong word from his own pen, even though they had never seen him in flesh (p. 173). His letter was the most remarkable method of nurturing for the church. What would have happened if he had not written his letters? Ball (1996) says, "Disciples of Christ from many cities came and went, seeking Paul's counsel and advice on matters of the Christian faith and carrying his letters to the church in the east" (p. 216).

\section{Fellowship}

Paul was trying to impart the importance of Christian fellowship which is very important in the Christian growth of maturity. "Not forsaking the assembling of ourselves together, as is the manner of some; but exhorting one another, and so much the more, as you see the day approaching" (Heb 10:25).

Paul emphasizes the necessity of growing together in Christ. Those of Christ's body-both Jews and Gentiles-must grow together to become one. They should no longer be "strangers and aliens" but "fellow citizens with God's people and members of God's household" (Eph 2:11-22).

Paul taught the significance of various gifts to nurture the body of Christ (church). 
It was he who gave some to be apostles, some to be prophets, some to be evangelists, and some to be pastors and teachers, to prepare God's people for works of service, so that the body of Christ may be built up until we all reach unity in the faith and in the knowledge of the Son of God and become mature, attaining to the whole measure of the fullness of Christ. (Eph 4:11-13)

He wanted to reach people for Christ and ground them in the Scriptures, which would help the new converts to grow spiritually. The Bible says, "Christ may dwell in your hearts through faith; that you, being rooted and grounded love ... know the love of Christ which passes knowledge; that you may be filled with all the fullness of God" (Eph $3: 17,19)$.

Paul turned people's attention from the literal rock to the real source of their sustenance - that is Christ, the Spiritual Rock. "For they drank of that spiritual Rock that followed them and that Rock was Christ" (1 Cor 10:4). Paul explains the sustenance work of Jesus Christ in the believer's life. He also clearly described that God is in control in nurturing the believers life, "Does not the potter have the right to make out of the same lump of clay some pottery for noble purposes and some for common use" (Rom 9:21).

\section{Prayer}

Paul advised the new believers to pray regularly and to remain faithful in their faith. The Bible says, "Pray in the Spirit on all occasions with all kinds of prayer and requests" (Eph 6:18); "pray without ceasing" (1 Thess 5:17). Paul helped the new believers to understand that their whole life should be a life of prayer. They should walk in constant communion with God. There should be a constant upward looking of the soul to God and a habitual walking in His presence.

Paul also informed the new believers about the interceding prayer of the Spirit, "In the same way, the spirit helps us in our weakness, we do not know what we ought to 
pray for, but the Spirit himself intercedes for us with groans that words cannot express" (Rom 8:26).

The New Testament gives valuable insights of núrturing methods from the life of Jesus Christ. The Apostle Paul followed Jesus' example in his ministry, and many church members were nurtured through his preaching, visitation, and counsel in his writings. The Jerusalem church played the role of spiritual guardians productively by maintaining loving relationships in their community, and their involvement in witnessing of the gospel strengthened the church.

It is not surprising that the Bible calls human beings "newborn babies" (1 Pet 2:2). God wants all to become more and more like Him. He works in people through His Spirit to nurture their hearts and adopt them into His family and become spiritually mature. The whole Bible is, in fact, God's intervention to nurture human beings in His character.

\section{Nurturing in the Spirit of Prophecy}

God has given people light through the Spirit of Prophecy and he gives principles that can be applied to nurture new believers who are joining the remnant church. It is crucial that Christians heed this information in order to impart successful growth in the new believer's spiritual life.

\section{Follow Up}

White (1907) describes the necessity of follow up and needful instruction that needs to be given to new believers.

Our efforts are not to cease because public meetings have been discontinued for a time. So long as there are interested ones, we must give them opportunity to learn the truth. And the new converts will need to be instructed by faithful teachers of God's Word that they may increase in a knowledge and love of the truth, and may grow to 
the full stature of men and women in Christ Jesus. They must now be surrounded by the influences most favorable to spiritual growth. (Review and Herald, February 14)

White (1886a) also mentions that "everything in the interpretation of the Scripture is new and strange to them [new believers], and they will be in danger of losing the force of the truth and receiving ideas not correct. In many efforts that have been made the work has been left incomplete" (Letter 60, cited in 1946, 334.3).

White (1897b) says that we need to do the work of an evangelist, water and cultivate the seed already sown. The new church that has been raised up should not be left destitute of help. The minister should develop the talents in the church to make the meetings to be more profitable.

White (1886a) emphasizes the importance of establishing the new believer's faith, It is poor policy to leave a few here and there, unfed and uncared for, for devouring wolves, or to become targets for the enemy to open fire upon. I have been shown that there has been much of such work done among us as a people. Promising fields have been spoiled for future effort by striking in prematurely without counting the cost, and leaving the work half done. Because there has been a course of lectures given, then stop the work, rush into a new field to half do the work there, and these poor souls who have but a slight knowledge of the truth are left without proper measures being taken to confirm and establish them in the faith and educate them like welldrilled soldiers how to meet the enemy's attacks and vanquish him. (Letter 60, under Teaching New Believers How to Meet Enemy, cited in 1946, p. 340)

Members have to remember that new converts need attention and care for their growth. White (1888a) says, "We are not to go away and leave them and have no further burden for them. They are to be looked after. They are to be carried as a burden upon the soul, and we must watch over them as stewards who must render an account" (p. 3). White (1948b) advised members to follow the example of Paul in doing nurturing.

The work should not be left prematurely. See that all are intelligent in the truth, established in the faith, and interested in every branch of the work, before leaving them for another field. And then, like the apostle Paul, visit them often to see how 
they do. Oh, the slack work that is done by many who claim to be commissioned of God to preach His Word, makes angels weep. (p. 256)

White (1894) penned, "We need to lead them along, to instruct them kindly and tenderly, and if the spirit of God is with us, we will know just what to say" (MS 42). White (1896) also wrote,

Those who have newly come to the faith should be patiently and tenderly dealt with, and it is the duty of the older members of the church to devise ways and means to provide help and sympathy and instruction for those who have conscientiously withdrawn from other churches for the truth's sake, and thus cut themselves off from the pastoral labor to which they have been accustomed. The church has a special responsibility laid upon her to attend to these souls who have followed the first rays of light they have received; and if the members of the church neglect this duty, they will be unfaithful to the trust that God has given them. (Review and Herald, April 28)

White (1970) says that we need to play the role of the spiritual parents in imparting the truth to spiritual babes and encourage them and pray for them for steadfastness. It is not surprising, many become discourage: Satan is attacking all the new believers and sends his agents to get back what he has lost (p. 351).

\section{Teaching the Word of God}

Studying the Word of God will direct the minds of the new believer and convince their hearts to understand truth. White (1905) says that care should be exercised to educate the young converts. They need protection from false teaching and to be taught to be faithful to all that Christ has commanded. The converts need to be trained to have a part in the great work to be accomplished in our world.

White (1970) emphasizes the significance of impressing the new believers with the knowledge of truth and to helping them to understand that it can be gained through labor and persevering study (p. 367). 
White (1915) mentions the danger of misunderstanding the truth and having a lack of foundation in the truth:

Many accept the truth without digging down deep to understand its foundation principles; and when it is opposed, they forget the arguments and evidences that sustain it. They have been led to believe the truth, but have not been fully instructed as to what truth is, or carried forward from point to point in the knowledge of Christ. Too often their piety degenerates into a form, and when the appeals that first aroused them are no longer heard, they become spiritually dead (p. 368).

White (1886b) says that the church needs to educate them and teach them as they embrace the truth on how to bear responsibility. God, who can make the seeds sown wholly fruitful, will help their efforts (MS 8a).

The new converts need to understand the importance of participating in the ministry for their spiritual growth. White (1948a) mentions the attitude of discipleship the ministers need to have to be implanted in nurturing the new converts. "They should not be at all satisfied with their success until they can, by their earnest labors and the blessing of God, present to Him serviceable Christians, who have a true sense of their responsibility, and will do their appointed work" (p. 398, 399).

\section{Visitation}

Visitation has an important place in nurturing new converts to recognize the needs of their physical and spiritual life. When church members visit the new converts they can bring relief to the challenges they face in their life. White (1888b) mentions the necessity of visitation, "Visit families, pray with them, converse with them, search the Scriptures with them, and you will do them good. Give them evidence that you seek their prosperity, and want them to be healthy Christians" (MS 8a). White (1897a) says, "Go from house to house, bearing ever the censer of heaven's fragrant atmosphere of love. Anticipate the 
sorrows, the difficulties, the troubles of others. Enter into the joys and cares of both high and low, rich and poor" (Letter 50, cited in Evangelism, 1946, p. 348.3).

White (1970) describes God's expectation to His church, "God requires His church to nurse those who are young in faith and experience, to go to them, not for the purpose of gossiping with them, but to pray, to speak unto them words that are 'like apples of gold in pictures of silver"' (p. 352).

White (1970) says that many ministers do not realize that the newly converted ones need nursing, watchful attention, help, and encouragement. They should not be left alone, a prey to Satan's most powerful temptations; they need to be educated in regard to their duties, to be kindly dealt with, to be led along, and to be visited and prayed with (p. $351)$.

When ministers visit new members they can see their needs; they may not be able to provide all their needs but providing what they can would bring blessing to them. White (1898) also mentions the necessity of meeting the needs of the new converts. "If they are poor and in need of food and clothing, minister to their temporal as well as their spiritual wants. Thus you will be a double blessing to them" (MS 63).

\section{Conclusion}

The plan of salvation was formulated even before the creation of the material universe. God already had the attitude of nurturing before starting His creation work. "He was chosen before the creation of the world, but was revealed in these last day times for your sake" (1 Pet 1:10). "The Lamb slain from the foundation of the world" (Rev 13:8) shows the clear picture of God's attitude of nurturing and His love towards human beings. The precious life of His Son was already offered even before humans were 
created. It can be said that nurturing emerges from the very heart of God, and the loving God did not ignore His creatures even when sins separated people from Him. Hanks and Shell (1993) wrote, "God cares deeply about people. He wants His children to have the same spirit of love and concern; He wants us to become healthy, active and growing Christians" (p. 90).

In this chapter principles and methods for nurture found in the Bible and the Spirit 'of Prophecy have been discussed. These included a devotional focus, witnessing, discipleship, the daily sacrificial system, childhood nurturing, Holy Spirit, the importance of teachers staying with their Bible students, lessons from nature, training small groups, visitation, letters, fellowship, sharing possessions, prayer, follow up, and studying the words of God.

In the next chapter a literature review will be conducted to find additional principles important to the nurture process. 


\section{CHAPTER 3}

\section{LITERATURE REVIEW}

\section{Introduction}

The work and process of Christian nurture is discussed using various terms like spiritual formation, spiritual leadership, sanctification, spiritual growth, growth in grace, etc. This paper uses the terms nurture and spiritual formation in the descriptive sense of being formed into the likeness of Jesus Christ.

\section{Nurture and Spiritual Formation}

Hanks and Shell (1993) define follow up as the spiritual work of grounding a new believer in the faith, which describes the nurturing process in the new believer's life.

Stanger (1989) concludes that "spiritual formation is growth in spirituality according to the image of Christ. It is the journey of the total person toward wholeness" (p. 16). He pointed out the description of Maxie Dunnman: "Spiritual formation is the dynamic process of receiving by faith and appropriating by commitment, discipline, and action, the living Christ into our lives to the end that our lives will conform to and manifest the living Christ in the world" (pp. 14, 15).

Wilhoit (2008) says that "Christian spiritual formation refers to the intentional communal process of growing in our relationship with God and becoming conformed to Christ through the power of the Holy Spirit" (p. 23). He continues to describe spiritual formation as a process, thereby implying that formation is a lifelong process that results 
from a multidimensional ministry, not just from a technique or program. Spiritual formation is becoming more like Jesus, and we can never accomplish this through our own power; we need the empowering of the Holy Spirit (p. 23).

Wiersbe (2000) mentions the responsibility of a spiritual Shepherd, "Spiritual shepherds are to introduce persons to Jesus, the Good Shepherd, and to nurture healthy relationships to him" (p. 24). He portrays God as Shepherd who commands his servant leaders to be shepherds. He explains clearly the biblical foundation of the spiritual Shepherd.

Wilhoit (2008) puts the definition of discipleship in this way, "Discipleship is the ministry that seeks to teach new believers essential Christian beliefs and also to train us in practices that are normal in the unfolding spiritual journey" (p. 188).

Barna (2001) describes Acts 2 as presenting the true picture of church and a model of true discipleship. "The followers of Christ engaged in worshipping, learning, relating, sharing, serving, evangelizing, and praying; the result was numerical growth, cultural influence, and the glorification of God" (p. 26).

Henrichsen (1988) draws out lessons from Jesus. His explanation of discipleship relates to the nature of God who alone can save human beings and that God is humanity's Savior. He explains the strategy of Jesus Christ to support his book title Disciples Are Made Not Born.

W. Arn and C. Arn (1998) explain the words of Christ in Matt 28:19-20 to display vividly the role of discipleship and the consequence of discipleship. "They saw a disciple as one who becomes a follower, who is taught, who is nurtured in the faith and then goes 
out to make disciples, they are then taught and nurtured in the faith and then in turn go out" (Arn \& Arn, 1998, p. 24).

God's intervention in the human life displays God's attitude of nurturing toward His creation. Brown (1994) says that God is a God of action who intervenes in His creation in general and in individual lives. He creates, sustains, and acts in planning their future (p. 34). He refers to Psalms, "The Lord reigns; let the earth rejoice" (Ps 97:1).

Lawless (2002) talks about the process of discipleship and points out that spiritual warfare and the process of a disciple making church is vitally important. He also says that the various experiences from the Bible and of the early church are exemplary.

The Spirit of Prophecy also suggests principles for nurturing new believers. White (1886a) mentions the importance of imparting the truth to new believers. Many times that work has been left incomplete in the ministry. The new believers are then in danger of losing the force of truth (MS 13). White (1886b) says that the church needs to educate them, teach them, and show them how to bear responsibilities and God will help their efforts (Letter 48).

White (1886a) says that the church cannot leave a few new converts here and there unfed and uncared for because they will become a target of Satan. Work half done can result in a poor harvest in what was a promising field. They are not well trained to fight against the enemy's attack (MS 13). White (1888a) says that the new converts are to be carried as a burden upon the soul. The church must watch over them as stewards who must render an account. White (1948b) says that "like the Apostle Paul, visit them often to see how they do. The slack work that is done by many makes angels weep" (vol. 5, p. 256). 
White (1894) wrote, "We need to lead them along, to instruct them kindly and tenderly, and if the spirit of God is with us, we will know just what to say" (MS 42). White (1896) also wrote that if the church neglects the duty of attending to the new converts they will be unfaithful to the trust that God has given to them. White (1970) additionally said that the ministers need to play the role of the spiritual guardians and give them nursing, comfort, and encouragement to the new believers. They should not be left alone, a prey to Satan's most powerful temptations; educate them in their duties, deal with them kindly. Visit them and pray with them to meet their spiritual needs (p. 351).

People need to understand the development of physical, mental, and spiritual. In nurturing church members need to be concerned in all these areas. White (1898) mentions that there is a necessity in meeting the needs of the new converts.

The new believers need to understand the knowledge of truth that can be gained through labor and persevering study (White, 1970, p. 367). White (1915) wrote that a misunderstanding of the truth and a lack of foundation in the truth will bring spiritual death (p. 368).

White (1970) suggests that believers must also be ready to become involved in discipling others. "They should not be at all satisfied with their success until they can, by their earnest labors and the blessing of God, present to Him serviceable Christians, who have a true sense of their responsibility, and will do their appointed work" (p. 345). The new believers must have a desire to witness of what they experience in their Christian life.

In nurturing the new believers, visitation in the home has an important place White (1888b) says to "visit families, pray with them, talk with them, study the 
Scriptures with them, and give them evidence that you seek their prosperity, and want them to be healthy Christians" (MS 8a). White (1897a) continues, "Go from house to house, bearing ever the censer of heaven's fragrant atmosphere of love. Anticipate the sorrows, the difficulties, the troubles of others, enter into the joys and cares of both high and low, rich and poor" (Letter 50, cited in Evangelism, 1946, p. 348.3).

\section{Preaching and Nurturing}

Stowe (1976) says that preaching has an important place in shepherding. He points out the biblical foundation of preaching from the Old Testament and New Testament. The Old Testament prophets were primarily preachers. Jeremiah said, “And the Lord said unto me, Behold, I have put my words in thy mouth" (Jer 1:9).

Preaching must be with the power of the Holy Spirit. Crabtree (2003) says that the task of the modern preacher is the same as Jesus imposed upon His own ministry. Every preacher is a candidate for the same endowment of the same anointing of the Holy Spirit (p. 62). Jesus identified himself with the Isaiah messianic prophecy and began His ministry with preaching, "He hath anointed me to preach" (Luke 4:18). He commissioned His disciples to do the same. "He went throughout every city and village, preaching. ... Then He called His twelve disciples together ... and He sent them to preach" (Luke 8:1; 9:1-2). Preaching has an important place in the mind of the Apostle Paul and also can be seen in his admonition of Timothy, "preach the word" (2 Tim 4:2).

Wofford (1999) introduces the transforming leaders as the ones who tend the flock of God with care. They lovingly nurture, protect, and comfort others in ways that produce growth (p. 18). In His reference to Jesus Christ as a transforming leader who 
fulfills the messianic prophecy by preaching the gospel and by bringing relief to the poor, the prisoners, the blind and the oppressed, the importance of preaching in the process of transforming can be seen (p. 24).

\section{Sabbath School and Nurturing}

The purpose of the Sabbath School is to make disciples for Christ and should include the nurture of spiritual growth in members. White (2002) points out that the Sabbath School is an important branch of missionary work that has a converting power, and gives knowledge to young and old because it awakens in them a love for sacred truths and a desire to study them for themselves; it teaches them to regulate their lives by its holy teachings (p. 11).

White (2002) continues to mention the sacred responsibilities that are with Sabbath School workers.

The Sabbath school should be a place where, through a living connection with God, men and women, youth and children may be so fitted up that they shall be a strength and blessing to the church. They should help the church upward and onward, as far as it lies in their ability, going from strength to greater strength." (p. 11)

The Sabbath School is a school of Christian living, not just an event on Sabbath mornings. The Sabbath School exists not only to minister to its members, but to train its members to minister to others.

\section{Prayer Meeting and Nurturing}

Prayer has important place in the church. Prayer is the life of the church, and it is the main source for the spiritual growth of the church. White (1995) says that prayer meeting is the pulse of the church body. It will display the true interest of the church 
members in spiritual and eternal things. It denotes the true spiritual condition of the church. A lifeless, backslidden church will not have appreciation for prayer meetings (p. 183).

According to White (1995) the church must pray regularly as Jesus prayed. The King of Heaven prayed, and He wept on behalf of humanity. Earnest prayer will move the arm that moves the world. The minister of Christ must pray if he or she would be refreshed from the presence of God. The church needs to pray much if they want to walk in the light, as He is in the light (p. 183). Macarthur (2005) says, "Prayer moves God; prayer changes things. Effective prayer accomplishes much. A praying church will be a victorious, growing, maturing community" (p. 61).

The prayer of Jesus in John 17 and the prayer of the Apostle Paul in his epistles show the importance of intercessory prayer for new believers. Morton (2003) says that there is nothing better a person can do for new believers than to pray for them. He also suggests that Scripture is rich with patterns of prayer (p. 57).

Armstrong (1983) says that the early church members were people of prayer (p. 43). He refers to the Scripture, "These all with one mind were continually devoting themselves to prayer" (Acts 1:14).

\section{Small Groups and Nurturing}

Wilhoit (2008) emphasizes the importance of small groups for Christian nurturing. Small groups create the opportunity to learn and to reflect on life's situations. Small groups can provide a perfect environment to both support and challenge people 
concerning what is needed to live the Christian life well. It is God's gift of grace given to a group of committed Christians that helps them learn and grow together (p. 124).

Schilt (1992) explains the biblical basis for small groups and how the influence of society has infected the Church with an individualistic form of Christianity. He is referring to gatherings in which people meet and form close relationships with one another, under the Lordship of Jesus Christ, in order to minister to each other's needs, to the praise and glory of God. The church has drifted from Christ-centered fellowship to individualistic Christianity. It happened first in society and then infected the church. This is in contradiction to what Jesus had in mind when He first established the church; the church is called to build relationships. He considered the church as a community, reflecting on the continuing presence of God in the world in and through the church.

Mallison (1989) also based his writing about small groups on the Bible and the history of renewal in the church. He listed various kinds of small groups and specifically included a nurture group. A nurture groups give initial help for beginners to establish a Christian style of living. He quotes Stephen Neill, "The Gospel must be brought back to where people live, in simple forms, and in terms of small and manageable fellowships" (as cited in Mallison, p. 1). He says that a small group is the basic building block of the life of a congregation and is fundamental to the development of individual and corporate Christian life. It has always been significant for renewal in the Christian church.

Martens and Swartley (1993) mention the unity that existed in the early church that resulted in sharing their possessions.

The members of the church are of one heart and soul because they all centered on Jesus, who unifies deep within. Thus dedicated to Christ and one another, no one claims private ownership of any possessions. All things belong to the Lord and are loan to them for the good of the community (p. 67). 
Barker, Johnson, Malone, Nicholas, and Whallon (1985) contribute their concept of small groups and examine the central ingredients of a balanced small group life. They also include a strategy for integrating small groups into the total mission of the church and provide a practical compilation of specific ideas, strategies, and helps. They say that people do need each other and that God made everyone to be in a relationship with Him and with each other. Much of a person's growth is dependent on the quality of such relationships and this can happen best in the context of small groups of committed Christians.

\section{Discipleship Training}

In the Old Testament Moses had training in the desert before he ministered to the Israelites. Wicker (1944) states that "God took forty years to teach Moses to be somebody and teach him that he was nobody" (p. 37). We see the same thing in the life of the Apostle Paul. Ball (1996) mentions that Paul did not go to the apostles in Jerusalem or to any others to learn the gospel he later preached. The gospel was revealed to him by God during his training in the Arabia desert (p. 76). Paul also mentions this when he wrote, "I received from the Lord Jesus what I also passed on to you" (1 Cor 11:23). The message presented to people needs to be the revelation from the Lord.

Coleman (1964) helps people understand the role of a disciple trainer. He says that the church cannot simply send out willing people to do the work and have glowing expectations. It is crucial that they have personal supervision and guidance until they are mature enough to carry the message alone (p. 100). 
Coleman (1964) presents the strategy of how Jesus trained His disciples that can be applied today. Jesus made observation from His disciple's experiences; their encounter with life situations enabled Jesus to understand the specific needs they had and then he showed them in concrete terms of practical experience how to change. He kept the disciples going forward towards a goal. His plan of teaching by example, assignment, and constant checkups brought out the best that was in them (pp. 99, 100).

Jesus concentrated on a few people to reveal His fundamental principles, and His strategy to win the world provides a good way for the church to implement its ministry. Coleman (1964) says, "One cannot transform a world except as individuals in the world are transformed, and individuals cannot be changed except as they are molded in the hands of the Master" (p. 24).

Coleman (1997) focuses mainly on Jesus' ministry with His disciples. He presents the basic strategy of Jesus Christ as He prepared a nucleus of laborers who would reach others. Jesus trained them to share that same vision and encouraged His disciples to begin their ministry where people were already open to the Spirit of God. The fundamental principle is that soul winning is completed only if the process of reaching out to others continues, not stopping just with one conversion. New disciples must become disciplers with the help of the Holy Spirit and must teach those they win to reach others for only then will the gospel spread to the whole world.

The Apostle Paul followed the strategy of Jesus and taught Timothy to do the same thing. Graham (1978) has commented on this strategy by writing that this is like a mathematical formula for spreading the gospel and enlarging the church. Paul taught Timothy, Timothy shared with people who would be faithful to carry on, and the process 
goes on and on. If every believer followed this pattern, the church could reach the entire world with the gospel in one generation (p. 147).

The observation to choose who would be faithful men and women must be done with thoughtful prayer. As this has an important effect with the ongoing process of ministry. The presence and blessing of the Holy Spirit will help to make right decisions and help the plan to succeed. A person cannot infuse the Holy Spirit but can ask for His directions and blessings (D. J. Burrell \& J. D. Burrell, 1897, p. 178).

People cannot produce what they do not have. Jesus taught His disciples from His own life and showed by a living example. Hanks and Shell (1993) state that knowledge was communicated to the disciples through the living personality of One who walked among them (p. 55).

Sweetland (1990) explains another responsibility of discipleship that new believers must be aware of. "The one who joins Jesus on His journey also incurs a missionary responsibility, must adopt a radical stance toward possessions and must be aware that there is a communal dimension to discipleship" (p. 25).

Young (2004) mentions the methods of Jesus' teachings and the parallel people might implement in modern management training. He advises church leaders to learn the lessons from the gospel. Jesus has left a variety of teachings in terms of argument, parable, example, and advice which are still valid today. The contents are in the Scriptures. Jesus left a great example which pastors can pick up and apply to their ministry (p. 70).

Adsit (1988) writes about the role of the Holy Spirit and the involvement of the body of Christ in the disciple-making process. He collected practical lessons from various 
disciple makers all over the world and talks about the levels of growth in the believers and explains what is needed at each level.

Coleman (1987) shows a pattern of disciple making and how the early church carried Christ's command to "make disciples of all nations." He reveals that while changes may need to be made in some specific courses, the basic principles of Jesus' ministry have remained unchanged since the apostolic age.

In the writings of Ellen White (1942) the impression of outdoor teaching can be seen. Jesus withdrew from the crowd to train His disciples to avoid the confusion of the city and went to the quiet place of the fields and hills. He used to turn the thoughts of His hearers from the artificial to the natural. By communion with God in nature the mind is uplifted (p. 54).

\section{Nurturing and Commitment}

People need to understand that the moment when a new believer decides to follow Jesus Satan will be working harder to disturb their decision and commitment. They need to understand their involvement in the battle, "For our struggle is not against flesh and blood, but against the rulers, against the authorities, against the powers of this dark world and against the spiritual forces of evil in the heavenly realms" (Eph 6:12).

Barna (2001) says, "The strength and influence of the church is wholly dependent upon its commitment to true discipleship. Producing transformed lives, and seeing those lives reproduced in others, is a core challenge to believers" (p. 24). 
Pentecost (1996) says that "discipleship involves commitment. It involves identification with Christ in His shameful death. Jesus said that 'if a man is not willing to forsake all that he has, he cannot be my disciple"' (p. 15):

Melbourne (2007) explains that "following Jesus is not easy. It requires faith, selfsacrificing love. It is challenging, but is doable, for we have a Guide, a cloud of witnesses, and great support" (p. 43).

Jesus also said, "If anyone would come after me, he must deny himself and take up his cross and follow me" (Matt 8:34).

As each person prepares to present the gospel and do nurturing work he or she needs to understand that they have to leave many things from the human side that could be a stumbling block to do the work of God. Melbourne (2007) says that "disciples of Jesus must not only be willing to follow His person but also His instructions, His mission, and His requirements. The first disciples left everything, livelihood, community, home, parents, families, and spouses and followed Jesus" (p. 13).

The work of discipleship and nurturing needs to be done with commitment; it is a process to help believers to accept the call with a hearty commitment. Melbourne (2007) writes, "Discipleship begins when one receives a call from the Master, accepts the call, and commits her or his life to the way of discipleship and the task it requires" (p. 15).

\section{Spiritual Formation}

Spiritual formation is the process of being conformed to the image of Christ. It is inspired by the Holy Spirit and grounded in Scripture and a faith community. Spiritual formation could be known as another term for Christian nurturing. McNeal (2000) 
emphasizes that spiritual formation is very important for spiritual leaders to develop their hearts. He emphasized heart-shaping which includes both divine and human activities.

Modern leaders can learn from the lesson of God's intervention in the life of Moses, David, Paul, and Jesus Christ to become successful leaders. If they examine how God shaped divine hearts in the lives of these spiritual leaders, they can understand the process of how God shapes the hearts of spiritual leaders. God changed the hearts of those spiritual leaders before he proceeded in shaping the hearts of the people they were going to lead.

McNeal (2000) introduced heart-shaping as an interactive process. God often works through leaders by using a variety of means in order to meet the needs of current situations. It is obvious that spiritual leaders need to know how God shapes their heart. This is very important especially for the leaders who are involved in the process of nurturing new believers, as different situations have different processes.

Blackaby and King (1998) emphasize the importance of developing an intimate loving relationship through a personal relationship with God for spiritual formation. They explain that leaders should focus their attention on God's program rather than on their personal desires, skills, abilities, and resources. They can hear the voice of God through an intimate loving relationship with God. God will reveal His purposes and plans to those who are attentive; the leaders need to be attentive to the voice of God in order to be involved in His work.

Blackaby and King (1998) mention that leaders should concentrate their energies on forming God-centered lives. They must seek God's perspective in every circumstance, become dependent on God and His ability to provide, and live a life focused on God. A 
God-centered life will reveal to leaders the ideal process of spiritual growth and development that needs to be done in the life of believers. Those who are involved in the work of nurturing cannot neglect this vital issue - a God-centered life—-seeking God's perspective in every situation.

Nurturing work is not easy. Leaders must have an intimate relationship with God to understand His direction. In doing nurturing work it may not always be possible to continue some specific strategy or method, but a willingness to adjust life to follow God's direction will give people the right direction. Blackaby and King (1994) say, "When you adjust your life to Him and obey Him, the Holy Spirit will be at work in you enabling you to accomplish all that God desires" (p. 77). In addition, various spiritual disciplines and experiences will lead people into spiritual maturity an enable them to impart the same knowledge to others. It is important to remember that leaders need transformation before they step out to minister to the community.

Ruby (1992) explains the role of the Holy Spirit in ministry. "Only in and through the person and power of the Holy Spirit can the Church and its leader equip, encourage and send forth the saints for the work of ministry in the church, the community and the world" (p. 38).

\section{Spiritual Leadership}

H. Blackaby and R. Blackaby (2001) define spiritual leadership by saying that "spiritual leadership is moving people on to God's agenda" (p. 20). A spiritual leader should move people from where they are to where God wants them to be. The first competency of a spiritual leader is not what he does, but who he is. Although many 
church leaders try to improve their leadership skills, the first factor should be a personal experience with God to understand God's agenda. In doing nurturing work Christians are involved in the process of changing the human heart and that needs to be done with God's power.

Blackaby and Blackaby (2001) insist that spiritual vision is God's promise and revelation. Instead of gathering people who will follow the leader, the purpose of spiritual leadership is to deliver God's promise to the people. The leader's priority should be God's instruction and the welfare of human beings. The leader could easily follow the majority, but God wants them to listen to Him to do His work.

God's providence is essential in doing nurturing work, and God is willing to give direction. Blackaby and Blackaby (2001) stated that the leader's priority is to seek God's providence. A spiritual leader should not only influence people through prayer, but also make decisions through the Holy Spirit's direction.

Kouzes and Posner (2007) provide some important core values in order to undergird practical aspects of spiritual leadership. Accordingly, they have pointed out five practices of exemplary leadership: (1) model the way, (2) inspire a shared vision, (3) challenge the process, (4) enable others to act, (5) encourage the heart (pp. 14-23).

Kouzes and Posner (2007) state that "leadership is a relationship" (p. 23). Even though they did not write much about spiritual leadership, a spiritual leader should be able to transform these practices into spiritual competencies in order to develop spiritual leadership successfully. A spiritual leader goes beyond building personal experience with God in order to have internal competencies and develop external competencies to lead his or her religious organization effectively. 
As Jesus used every opportunity to nurture His disciples, leaders also can do the same thing. Melbourne (2007) says, "Jesus was indeed a disciple-gathering teacher. He used every opportunity to call, train, educate, and nurture disciples. He was never too busy to help a needy soul" (p. 121).

Leaders and pastors need to understand their responsibility is not to do all the work of nurturing. The responsibility applies to all members, and the spiritual life of the members will be uplifted when they play an active role in nurturing work. Leaders and pastor must empower and train their congregation to do the work of nurturing. Melbourne (2007) gives meaningful insight to his comment on the role of a disciple,

The Shepherds do not beget sheep. The sheep reproduce themselves. Nor does the shepherd give milk to the sheep. The sheep nourish each other. The shepherd merely leads the sheep to green pastures. The believers must be able to give birth to other believers, and then teach them the rudiments. (p. 18)

Church leaders need to lead new believers toward spiritual maturity, helping them be "in Christ" so that His character, His love, and His grace are found in them. That is the goal. The work of nurturing among the Reang tribe requires humility and the attitude of servant leadership to have a good impact on their society. Greenleaf, Spears \& Covey (2002) write about the attitude of a servant leadership and insist that the spiritual leader should have a spirit of servanthood. In Servant Leadership, Greenleaf et al. stated that Jesus Christ's ministry demonstrated servant leadership. Whereas the religious institutions and leaders of those days had lost their servant spirit and had egoistic minds, Jesus displayed the true role of leadership which was "servant leadership." 


\section{Conclusion}

In this chapter, a variety of relevant principles from the literature was examined, such as spiritual formation, spiritual leadership, and nurturing. Obviously, spiritual leaders should motivate people to move toward God's purpose. In order to display their leadership spiritually, they should be equipped for the ministry by having a personal relationship with God. In addition, they should recognize that leadership is a relational process influenced by the Holy Spirit so that every member can be involved in the shared vision.

Merrill and Shelly (1984) say that "churches cannot assume the job is done once someone makes a decision for Christ. We must fully incorporate each individual into the life of the church. And that job never ends" (p. 13). 


\section{CHAPTER 4}

\section{CULTURAL AND RELIGIOUS CONTEXT}

\section{Introduction}

This chapter focuses on the cultural setting and religious context of the Reang Tribe. The brief cultural setting, religious beliefs and practices are briefly mentioned. It is not possible to give many details due to the limitation of the resources available. The impact of Christianity is written briefly from my personal knowledge and experiences. The resources are also mainly based on my personal experiences and some that I found on the web.

I experienced living with the Reang tribe during three years of my ministry when I worked under the Mizo Conference in Jampui Hills, North Tripura, and India. There are 10 Mizo villages where I can use my own dialect, but the surrounding areas are mostly occupied by the Reang tribe. There are three locations for a Reang refugee camp where the refugees come from Mizoram, a neighboring state of Tripura. I ministered in the area of the 10 Mizo villages, the surrounding Reang villages, and the Reang Refugee Camp.

Refugees come to Tripura due to political conflicts arising between the Mizo and the Reang tribes. Many times the tension of these conflicts has accelerated. The leaders used to inform us to stay at home to avoid the conflict's consequences. 


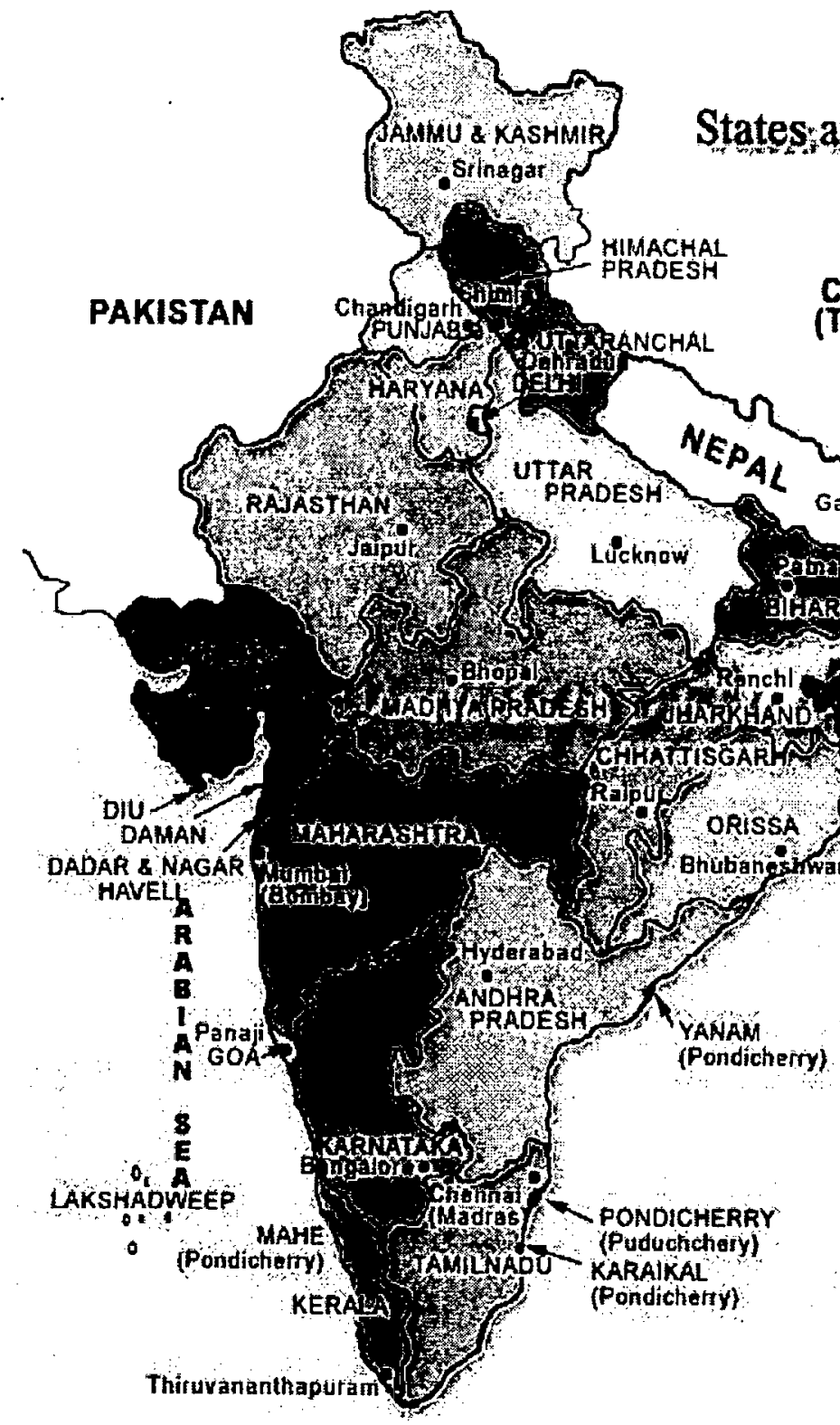

Copyright e Compare Intobase Pvi Lto. 2003
NDIA

CHINA

ARUNACHAL PRADESH

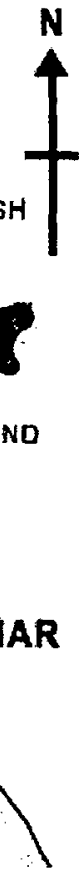

BAY OF BENGAL

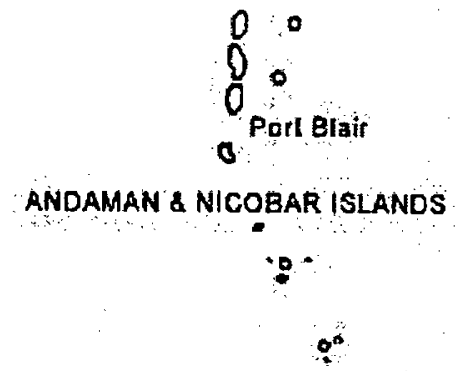

O Map nut to Scale

Figure 1. India: States and union territories. 


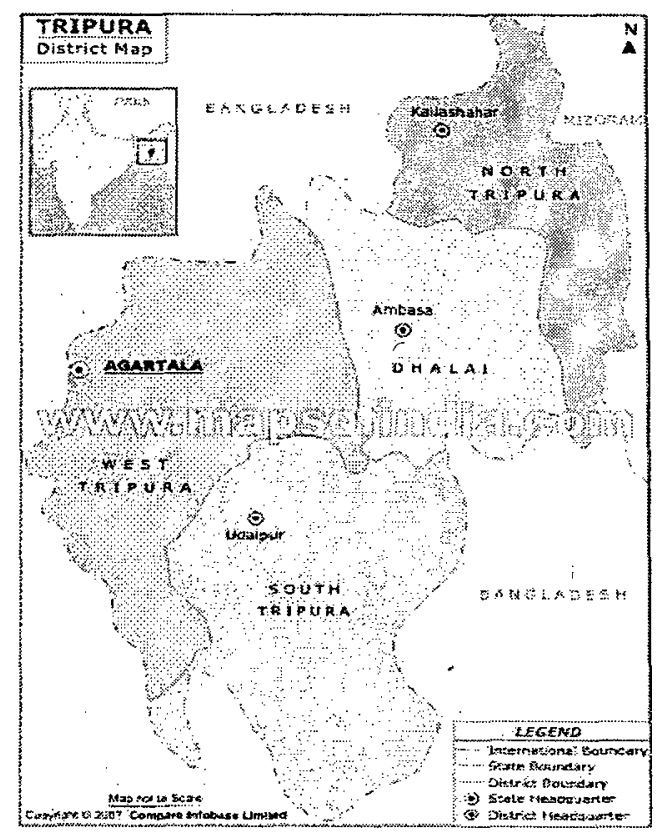

Figure 2. Tripura district map.

\section{Historical-cultural Context}

An understanding of the Reang cultural background will be helpful in order to approach the Reang community with a Christian message. The majority of the Reang tribe is known as being "backward," both educationally and economically. The government of India still recognizes them as a "primitive" group.

\section{Reang Tribe Background}

Reang is one of the 21 scheduled tribes (the Indian government gives special aid to the indigenous rural communities who are officially considered disadvantaged) of Tripura. Tripura is one of the smallest states in Northeast India. Debbarma (2005) mentions the name of the Reang in this way, "It is difficult to ascertain as to how the Bru people came to be known as the Riang or Reang. Riang or Reang is only one of the clans of the Bru. The term Bru indicates man or human. Thus the use of the term Bru may be 
appropriate rather than the use of the term Riang or Reang" (pp. 221, 222).

There are many stories about the origin of the Reang people and there are three different familiar views about the original home of the Reang. Dev (2005) writes the first view is that the Reang people migrated for the first time into Tripura from the Shan State of Burma, now Myanmar, via Chittagong Hill tracts in the 14th century during the reign of Maharaja Ratna Manikya. Samanta (1980) has written another view of the Reang origin. The Reang people came to Tripura from the plains of the Maiyanithlang area of the Lushai Hills, bordering on and stretching into the Arakans in Burma. It is probable that their language is closely related to the Austor-Asiatic family of languages. In that case, the Reang people could be close kin of the Kuki-Ghins. They could be the lower caste among these clans, and due to heavy demands made on them, they migrated to the Karnaphuli Valley of Chitta-hill tracts (Bangladesh) where they set up small settlements during the reign of Ratna Manikya in the fourteenth century. Later, when the Kukis followed them there and sought to reassert their authority over them, they fled to Hill Tipperah (now known as Tripura). They spread from Amarpur and gradually inhabited the whole state. The feeling of master and slave that must have existed in the past between the tribes of the Kuki-Ghin group and the Reang because it is still apparent today wherever these tribes have come in contact (Samanta, 1980, p. 44).

Dev (2009) describes the third view that the Reang are the original inhabitants of Tripura. At one time the border of Tripura extended from Burma (Myanmar) to the shores of the Bay of Bengal, and the Lushai (Mizo) district of Assam was within the geographical boundary of Tripura. So, on the basis of these views, it can be said that the Reang share with the original inhabitants of Tripura. It also cannot be denied that the 
original habitation areas of the Reang spread over the hill tracts of Mizoram and Chittagong, where these regions adjoined Burma (Myanmar). Some marks of Burmese culture and language were stamped on them, which is highly perceptible in Bengali culture, language, and education of all the Tribal clans of Tripura.

According to Debbarma (2005) many scholars have suggested that the migration of the Reang tribe to Tripura is based on assumptions and reconstructions on the basis of ethnicity and language. None of the anthropologists and social scientists has been able to give a definite time of their occupation of the present area. Debbarma concluded that the Reang people linguistically and ethnically belonged to the Bodo group of the TibetoBurman family. Their language is Kokbru (p. 222).

Wikipedia has a similar comment about the Reang people. Reang people speak the Reang dialect which is of Tibeto-Burmese origin, which often is referred to as Kaubru. The Reang sometimes call themselves Bru and they are often called "Bru" by others. They mainly live in the North Tripura and the South Tripura districts of Tripura State in India. Their appearance is mongoloid. The Reang constitutes the second biggest group among the tribal population in Tripura (Wikipedia, s.v. Reang People).

\section{Reang Community}

The Reang tribe maintains a disciplined community. The head of the community is given a title of "Rai." He has power in all matters of internal disputes. He is responsible for the welfare of the entire Reang community. In case of any minor or major dispute, he will pronounce the last word of judgment. The Reang community seeks justice mainly from their leader and they generally avoid the normal court for justice. Justice is done 
according to the principles of natural justice. Dev (2009) says that Rai has the highest title of honor among the Reang community and he is the supreme authority. The Reang community functions under the guidance of this one man.

Samanta (1980) wrote about the impact of the individual Reang family to their community. The Reang family practices a joint family tradition. The primary functions of the Reang family are to uphold the spirit of integration in the social life. This integration is achieved through care, education, work, loyalty to authority, and observance of family usage (p. 48).

\section{Occupation}

The Reang are primarily an agriculturist tribe so cultivation is the major source of sustenance. The majority still practice jhum cultivation (slash and burn cultivation) but a few of them have upgraded to modern agricultural practices. There some who are now entering into the modern business world.

The education of the Reang tribe of Tripura is one of the biggest challenges leaders face in the ministry. The children of the Reang tribe rarely go to the local schools and in many places they still do not have any schools. The parents' minds are troubled about the future of their children. Some of the educated people are employed in government jobs and some occupy very high posts in the administration, but the majority of the people are still very backward when it comes to education. 


\section{Marriage System}

Marriage plays a significant role in the Reang Community. They are trying to preserve their tribe by following endogamy. Wikipedia classifies the Reang tribe as an endgoamous tribe having very little contact with surrounding tribes. There are some difficulties in following this practice as they gradually mixed with some of the other tribes. Recently there have been some inter-tribe marriages and inter-caste weddings in various places (s.v. Reang tribe, marriages).

The Reang community practices arranged marriages. Samanta (1980) says, "In rare cases 'love marriages' are permitted” (p. 48). Wikipedia briefly describes the Reang marriage system as where the respective parents negotiate the marriage of their children. The arrangement is done by the matchmaker known as Andra, who goes to the future bride's parents for negotiation. There will be a celebration when the arrangement is finalized. The Ochai (Priest) will perform the wedding ceremony. Child marriages are not permitted, but they do allow a widow to remarry. Widows are prohibited from wearing ornaments until one year has passed after the death of their husbands. Widows and widowers are not allowed to participate in any entertainment, programs, or activities within one year of the death of their spouse. The remarriage of widows and widowers is allowed after one year of the death of the spouse. A widower is not allowed to marry an unmarried virgin girl. The marriage tie is very strong; men cannot simply decide to divorce without the consent of their wife. They execute a heavy penalty to those who are alleged to have an extramarital affair (s.v. Reang Marriage System).

The Reang community has a practice that is very close to the Dhowry system. The bridegroom stays in the future bride's house for some period of time, the duration 
different in many places. Debbarma (2005) says that the duration could be two to three years or more. He mentions this period as a probation time, where the prospective bridegroom shows various skills to convince the prospective father-in-law that he excels in every field such as shifting cultivation, hunting, trapping birds, fish, animals, and building houses. He needs to fully satisfy the parents of the girl (p. 224).

Samanta (1980) says that there is no objection if the couple starts marital relations during this period. If the boy leaves before completing the period, he has no right to marry the girl. The girl will be free to marry some other person. If the future bride's father agrees, the boy can send someone on his behalf. Nowadays in some places money is accepted. After the probation period is completed, the couple stays in the boy's house (p. 48).

\section{Culture and Value System}

There are some interesting cultural and value systems in the Reang community. Samanta (1980) wrote, “The Reang have a rich material culture" (p. 49). The women knit and dye their own cloth. They wear expensive silver coins as necklaces and dress in colorful loin cloths. They like flowers more than ornaments and use them to decorate their hair, ears, and nose. They used to reject any artificial make-up, but now soap, perfumed oil, and other scents are accepted.

Dress and ornaments have occupied an important place especially among the women. It is crucial to understand this before they are approached with the Adventist standard of dress and ornaments. Wikipedia mentions that the Reang women love personal decoration and take much care with their makeup and hair decoration. They love 
ornaments, flowers, and cosmetics, especially a necklace of silver coins (s.v. Reang dress and ornaments).

Samanta (1980) has interesting comments on how they honor special guests.

They give a hearty welcome to the visitors. The whole village is decorated with flowers, and men and women turn out in all their finery to greet an honoured guest. All the women touch his feet while the wife of the headman presents him with many bottles of wine which the whole village shares. When he departs an egg is placed on a banana leaf on the outskirts of the village. The departing guest is then asked to gulp down a glass of rice-beer and, amidst the beating of drums, the egg is slit cleanly into two with a sharp dao. Everybody eagerly watches as the two pieces sway on the banana leaf. If one of them is convex up and the other concave up, it is considered very auspicious and everybody rejoices and drinks. It is in this festive spirit that the guest departs. (p. 49)

\section{Religious Context}

The indigenous religious beliefs of the Reang Tribe monitor the societal life of the tribe in various ways. It is essential to understand their indigenous beliefs and practices in order to convince them of the truth.

\section{Religious Beliefs and Practices}

Christianity brings remarkable changes to the Reang community but there are many people who still cling to their indigenous beliefs. Samanta (1980) says that most of the Reang who do not accept Christianity call themselves Hindus of the Shakta cult. There are a few people who have adopted Vaishnavism, given up fish and meat, and have given up animal sacrifices (pp. 49, 50).

Samanta (1980) wrote about their strange beliefs of the supreme being known as Achu Sibrai.

Achu Sibrai, the Supreme Being, was engaged in deep meditation on two sacred stones for the creation of the Reangs. Nearby his wife, symbolized by a bird, while 
hatching two eggs, felt hungry and picked up these two stones, taking them to be fruit. She carried them to her nest but not being able to eat them, she hatched them. After 12 years, Dcbtarani and Deblakshmi were born from these stones. They became the ancestors of the Reang people. Sammlimland and Tampuima, born of the two eggs, became the ancestors of the Reang deities. Achu Sibrai woke up and blessed Debtarani and Deblakshmi and instructed the deities to keep a watch on them. Since then the deities live in this world, threatening the human beings with death and disease when the world became sinful. (p.50)

Samanta (1980) says that the evil spirit known as Buruirao is worshipped near their home or the boundaries of their villages. A forest fire is believed as the visible form of the ghost and they also believe that ghost makes the thumping sound heard in a bamboo forest (Samanta, 1980, p. 50).

Evil spirits threaten the lives of the Reang tribe in many ways. To appease the spirits, they must perform rituals and sacrifices. They fear that the spirit, if not worshiped, will curse the family and cause many failures in their life. Samanta (1980) says, "It is believed that diseases are caused by some specified deities and evil spirits who have to be regularly appeased. For any disease, medicine is prescribed by the vaidya (medical man), but it cannot be warded off by medicine alone; rituals have to be performed by the achai or oja" (pp. 50,51).

Samanta (1980) says that they perform rituals every year before cutting the jhum (shifting cultivation); for the prevention and cure of a disease; for the protection of a newly-built house; for protection against snake-bites, for rains, for wealth; for the welfare of a clansman; and for various other individual and clan needs. They also used to offer worship to all the rivers, including the Gumti, Karnafuli, Mahuri, and Feny. They also perform Lakshmi puja, Ker puja, Matungi puja, Tripura Sundari puja and Chitragupta puja every year (p. 51). Puja as a form of Hindu worship. 


\section{Ceremony of Death}

An understanding of the ceremony of death (cremation) in the Reang community could be helpful in order to teach the biblical concepts of the dead. Samanta describes the process of cremation:

Reangs cremate the dead, and the bones are kept for a year in a shed (simangnok). The bones are then brought back to the house by a widow and the shed is burned down to drive away the spirit. After a period of feasting and dancing, the bones are immersed in the river on a bamboo raft. Belief in the immortality of the soul and its reincarnation is very strong. It is believed that life divides into two parts, the soul mixing with the wind and the body taking refuge in water. (Samanta, 1980, p. 45)

Wikipedia briefly mentions the two types of burial rites known as broksakami and

\section{kthuinaimo.}

Broksakami: The deceased body is first bathed with alkali water or soap known as Chobtui and water obtained from the washing of raw rice known as Mairangtwi. They clothe the body with a new clean Rikatouh, the head is wrapped with another piece of rikatouh like a hat. In the case of a woman, they use cloth specifically designed for women known as rnai and rsa. A fowl is sacrificed in front of the feet of the corpse. An earthen pot filled with meat and rice is placed at the feet of the deceased and a ritual dance follows throughout the night. They distribute rice beer to all the mourners, except the family members of the deceased. The next morning the body is laid on a pyre and they normally perform cremation near a river or stream (Reang Broksakami)

Kthoinaimo: It is a ritual practice of a well wishing offering to the spirit of the dead. The soul or Laotau of the deceased remains under the control of the Sisi Manji, the son of Buraha, for a year. They believe that sisi manji is the protector of the soul. The widow of the deceased offers dried rice, meat, fish, fruits, and wine in the name of Laotau and sisi manji on the day of the kathainaimi. The soul is worshiped over a period 
of one year. They immerse the ashes in the river or in Gomati River at Dumbur, according to the ability of the family (s.v. Reang Kthoinaimo).

Dev (2009) says, "Reangs believe in re-birth and the next world. Hence they attach a high value to honest deeds. They believe that the soul of the dead does great good to the family. If the annual rituals for the dead are not observed, the soul becomes villainous and hurts the family as a villain" (Indian folklore).

\section{Impact of Christianity}

The materials presented in this section are from my own experience of three years among the Reang. The Seventh-day Adventist Church first started its ministry to the Reang community in the late-1960s, after certain other denominations were well established.

\section{Impact of Various Christian Denominations}

The spread of Christianity by Western missionaries from different denominations brought changes and, to some extent, improved the social, educational, and economic status of the Reang Tribe. In the Reang community the younger generation is keen on adopting Christianity, compared to their forefathers who have been closely attached to Hinduism.

The Protestant denominations such as the Salvation Army, Presbyterians, and Baptists were the pioneers in approaching the Reang community with the Christian religion. The Adventist volunteers reached the Reang community only after many other churches were established by different denominations. The interaction of the Presbyterian 
Church, Baptist Church, and the Salvation Army with the Reang tribe contributed to the outlook of the Reang tribe toward Christianity.

In some areas the missionary workers of other denominations were influenced more by the culture of the Reang community than by the biblical principles of Christianity. The negative influences of these Christian missionaries resulted in complications among the Reang and impacted their view of Christianity.

The poverty of this tribe brings many challenges for missionary workers. The distribution of clothing and other material to ease the people's daily life could divert their attention and cause them to misunderstand the main goal of the gospel. The expectation of clothing and the development of their rural areas seemed to cause them to make a quick decision to join any denomination that was available to them. It seems that the other denominations used to meet these needs in many places and just asked them to make their decision to join the church. This gives proof when in interaction with the Reang tribe they seem to not understand the role of Christianity. For many of them it is just like joining a political party. This is one of the biggest hindrances for them to understand the true nature of Christianity and they do not hesitate to join any denomination which can ease their difficulties.

Seventh-day Adventist Approach to the Reang Tribe

The Adventist Church started working among the Reang Tribe during the early 1960s. According to the record of the Mizo Conference, Pastor C. Saikhuma and his family entered Tripura to do ministry among the Reang Tribe in the late 1960s. After three decades, in 1992, global mission pioneers entered North Tripura. In 1996 they 
entered South and West Tripura. According to the current record in West Tripura there are 7 organized churches and 15 lamb shelters, and are presently building 4 more. In East Tripura there are 6 churches and 21 lamb shelters (Mizo Conference Record Book, 2010).

The first challenge for the Mizo Conference workers is that the Reang tribe speaks a dialect which is completely different from the Mizo dialect. The interaction of Reang and Mizo helped some of the Reang people to understand the Mizo dialect and these people are the means of conveying the message. God gave the "gift of tongues" (the ability to learn languages) to some of the Mizo Conference workers and they were helpful in communicating the Adventist message. Some of them started work on translation of our basic doctrines into the Reang language.

There is a much larger problem to deal with in order to bring about an all around development, as the majority of the community is below the poverty line. The missionary workers have accommodation problems at the beginning of their ministry in various places. The Reang tribe in the village areas and in the Refugee camps did not have extra housing and they could not provide accommodation for the Adventist workers even if they were desiring to rent facilities. The other challenge was that Adventists were not welcome to enter some areas to present the Adventist message. But the Lord has many ways to convince this people and open the way to reach the Reang community.

The major challenge addressed in this project is that many converts don't understand the real meaning of being a Christian. Their search for relief from poverty that may be somewhat addressed by the churches is valid but they need to be led into an authentic experience of discipleship.

Presently, missionary workers have received invitations from various places to do 
work and are having a lot of nurturing to do. It is very hard to ignore the invitation from other places where they are open to the Adventist message. This is the challenge we are facing because the nurturing work cannot be neglected.

Malaria is prevalent in Tripura. It has been a dilemma for the Reang tribe. This is one of the problems for missionary workers in their community. God's providence has miraculously protected the ministers on many occasions and they are able to minister to the sick of the Reang tribe.

\section{Needs and Objectives of the Mission for the Reang Tribe}

Poor economic conditions affect the Reang tribe in various ways. The struggles for their daily survival make it difficult to maintain good discipline in the community. The majority of the Reang tribe in the village areas do not know how to read, so cannot use a hymnal or read the Bible. Nurturing new believers through written material is not effective for the majority of them are illiterate.

Since jhum cultivation is the main occupation of the villagers many of them cannot attend meetings regularly. The Jhum cultivation requires a lot of manual work so they spend most of their time on their farm and sometimes do not come home for a week or two. The parents need to work regularly to feed their children; if they do not work for a few days, they do not have anything to eat as many of them struggle to get their daily food. The other serious problem is that many men drink and they do not mind spending the only money they have on drink. The challenge of the missionary workers in the Reang community is to develop their-social life and spiritual life harmoniously and see God's plan to uplift the society. 


\section{Challenges in Education and Occupation}

Many places are requesting Adventist workers to open a school to educate their children and this is one of the biggest challenges for Adventist ministry among the Reang community. It is difficult to provide education for all of them because of financial problems and lack of workers. The Adventist Church has established a school in some of the areas for their children and many of them are being educated in our institution. It is painful to see the future of the children where they do not have an opportunity to have a proper education.

With the help of some lay members some of the young people are having a privilege of studying theology at Spicer Memorial College. These few people who are receiving an education are expected to play an important role in bringing changes in the spiritual and social life of the Reang community. Due to financial problems it is not possible to send many of them for higher learning. It would be a great blessing if many more young people could be involved in higher study because they could make a bigger impact on their society. It is obvious that bringing development to the whole tribe within a short time is very difficult. Education plays an important role to change the condition of the next generation of the Reang tribe.

The illiterate Reang are ignorant of their future. They find it very difficult to make future plans, and making a five or ten year plan is too far in the future for many of them. The struggle of daily survival seems to disturb their mind and it is very difficult to make future plans with their current situation. Interaction within the community to give advice and guidance would be helpful in making plans with their understanding. Suggestions to improve their agriculture and animal husbandry could be a helpful means to convince 
them.

The average members of the Reang tribe are not hard working in such a way to uplift their family and societal economic condition. They practice jhum cultivation and need to look for better forest land for their farming every year. They are nomads; many of them do not have a permanent residence but move from place to place. The government used to provide financial support to establish some kind of a village, but after they used all the money they would go to another place. In their present condition, animal husbandry, such as a poultry farm, cattle, goat farm, and sheep farm, etc., could be useful with proper guidance to uplift their critical condition.

\section{Difficulties with Indigenous Religious Practice}

The majority of the Reang community is Hindu but they do not have regular worship services in their indigenous religious practice. It is really hard to change their habits of worship style. They used to build a small temple in their house and just pray whenever they felt it was needed. They do not have a good discipline of worship. Their religious lives do not have much impact on their secular life. When they become Christian, they need to change many things in their secular life, which was not really necessary in their previous religion.

I need a closer walk with God to work among the Reang tribe. I think I need a higher commitment to uplift their spiritual and physical condition. I need to pray more to understand God's vision for this people and submit my heart to move forward according to that vision. One of the challenges I face is to live with them to be their mentor and give them the training they need to change their lifestyle. 


\section{Baptismal Growth and Decline}

The Adventist message brings remarkable changes among the Reang tribe. Even though there were some obstacles to approaching them at the beginning, the baptismal rate has been constantly growing within the last decade. But the challenge the Adventist ministers encounter in the Reang community is new member retention. On many occasions the Reang people are quick to make the decision to be baptized but they appear to have a preconceived idea of Christianity. I believe this could be the influence of the other denominations and because of their indigenous religious beliefs. The minister who focuses on the number of baptisms could be tempted to do a baptismal service after he finished a certain presentation of the doctrine. It is obvious that the Reang tribe needs to be informed of the role of Christianity and the responsibility of being a Christian. This attitude of the Reang tribe toward baptism raises baptismal growth, but since many of them do not experience true transformation, the dropout rate is very high. The baptismal candidates are not well acquainted with Adventist beliefs and also need spiritual transformation. The baptismal services in many places were conducted prior to the development of a personal sincere desire to be a follower of Jesus Christ.

The Mizo Conference does not keep detailed baptismal growth and dropout records for the Reang tribe, so it is difficult to give an accurate statistical report with the information they provided. According to the latest report of March 2010, there are 5,007 baptized members but my estimate is that only about 50 percent of them have remained faithful while the other 50 percent have backslidden, or who are missing in the Conference record book. This project focuses on how to reduce the 50 percent dropout rate, and how to nurture them in their spiritual growth. 


\section{Conclusion}

The religious practice and cultural setting presented in this chapter mainly focused on the whole tribe setting. Even though they have formal religious practices and a cultural setting, many of them are not really applied in many areas, especially in isolated places where they do not have educated people and where they cannot afford to perform the details of their regular religious practices. The impact and influences of their indigenous practices still have an impact on some part of their outlook and lifestyle. It is significant for a minister to understand the background of this people from the higher classes of the tribe and the educated people to facilitate a meaningful approach in the remote areas.

There are so many things involved and so many things to accomplish in order to uplift the present condition of the spiritual and social life of the Reang tribe. God's special guidance is needed to meet the challenges. It is obvious that God has a plan for the Reang tribe to bring them closer to Him. Those ministering to the Reang tribe need to seek God's plan in order to reach their hearts. 


\section{CHAPTER 5}

\section{A MODEL TO NURTURE REANG NEW BELIEVERS}

\section{Introduction}

This chapter deals with a model for developing spiritual maturity among Reang believers. I relate my personal experience with biblical methods of nurturing to develop the strategies in this chapter. Reaching this community with the Adventist message and with the intention of bringing them to spiritual maturity has many complications in terms of the cultural context and religious background. It is very obvious that without God's intervention the plans and strategies to bring spiritual maturity would be futile. The workers in various places must be in tune with the plans and programs of God. A fundamental ministry structure built up according to God's plan will bring a greater chance of success; therefore, it is essential to find out what God's plan is to address the current critical situation of the Reang tribe.

In my personal observation there are several reasons for failure in the current nurturing methods for the Reang tribe: (1) the ministers have not been well acquainted with the culture and religious concept of the people, so are not able to contextualize the Christian message in ways that it becomes understandable for them; (2) there was insufficient preparation for the evangelistic meetings and failure to complete follow up work that is vital for the growth of the new believer's spiritual life; and (3) the preparation of lay members to actively participate in evangelism seemed not to be the 
prime concern of the ministers, as the ministers did not give essential training to the lay members who could be actively involved in the out-reach program.

\section{Spiritual Preparation Seminar for the Workers}

The spiritual preparation of the mission workers is imperative to implement successful nurturing methods for the Reang community. The training will be held to make sure that the workers are maintaining an intimate relationship with God and they are moving forward according to God's vision and plan for the Reang tribe.

The training will be designed to help the workers to re-examine their life and the strategy they used in their approach to the Reang tribe. It is important to establish an intimate relationship with God before becoming involved in the ministry. We cannot expect them to be what we are not. Pentecost (1996) says, "We are not chosen first to serve, but rather to be with Him; it is more important to be occupied with Christ than it is to be occupied for Christ" (p. 108). Henrichsen (1988) also says, "When we invest in the lives of other people, we transmit not only what we know but, more importantly, what we are; each of us becomes like the people with whom we associate" (pp. 10,11).

The request to conduct the seminar will be submitted to the Mizo Conference with the expectation that those current workers ministering among the Reang tribe would attend the spiritual preparation seminar. The subjects and the methods in the seminar have been developed from my experience and evaluation. During the training the following subjects will be covered and emphasized to bring spiritual maturity among the Reang tribe. 


\section{Devotional Life}

Daily devotions can easily be neglected with many responsibilities in the ministry. I was in charge of the church building and establishing a new school during my ministry among the Reang tribe. I knew I should not neglect my daily devotions but when there were so many things to accomplish, I often did not take time for my devotions. I worked very hard for the physical development of the tribe but when I missed my regular devotional time I felt that they did not receive what they needed for their spiritual development. The importance of daily devotions and a prayer life will be emphasized in the seminar. The workers in the Reang community need to understand that maintaining an intimate relationship with God is a must to move forward according to God's vision. John the Baptist left a good example. White (1915) says,

John the Baptist in his desert life was taught of God. He studied the revelations of God in nature. Under the guiding of the divine Spirit, he studied the scrolls of the prophets. By day and by night, Christ was his study, his meditation, until mind and heart and soul were filled with the glorious vision. (p. 54)

White (1915) also has more to say on the subject:

The Redeemer will not accept divided service. Daily the worker for God must learn the meaning of self-surrender. He must study the word of God, learning its meaning and obeying its precepts. Thus he may reach the standard of Christian excellence. Day by day God works with him, perfecting the character that is to stand in the time of final test. And day by day the believer is working out before men and angels a sublime experiment, showing what the gospel can do for fallen human beings. (p. 113) 
White (1915) mentions that the necessity of a fresh revelation of Christ in our daily experience is in harmony with His teaching. Every day we may move toward perfection of the Christian character (p. 274).

The example of Enoch's life reveals the importance of spending quality time for devotions, with the time spent in solitude being the source of his success in his spiritual life. White (1915) says,

In the midst of a life of active labor, Enoch steadfastly maintained his communion with God. The greater and more pressing his labors, the more constant and earnest were his prayers. He continued to exclude himself at certain periods from all society. After remaining for a time among the people, laboring to benefit them by instruction and example, he would withdraw, to spend a season in solitude, hungering and thirsting for that divine knowledge which God alone can impart. (p. 52)

\section{Prayer and Meditation}

Prayer and meditation was an important part of Christ's ministry. Jesus was filled with the Holy Spirit before he started the ministry but Jesus still prayed regularly to renew His relationship with the Father. The Bible says, "Jesus often withdrew to lonely places and prayed" (Luke 5:16). These regular practices of prayer established the constant communion with His Father (John 14:10).

White (1948c) says

We need to be converted daily. Our prayers should be more fervent; then they will be more effectual, Stronger and stronger should be our confidence that God's Spirit will be with us, making us pure and holy, as upright and fragrant as the cedar of Lebanon (p. 252).

\section{Prayer Life and Meditation}

The workers will be trained how to do an evaluation of their prayer life and how they meditate. They will be trained on how to keep a journal, and will practice writing 
down the message they get from their meditation through the Word of God and prayer. This will help them to develop their spiritual disciplines. They will be requested to keep their journal and send a copy of it to their respective circle leaders at the end of the month.

During the training the workers will practice meditation on God's Word; they will read the Scriptures slowly, thoughtfully, and with an open heart. After meditating on the special word or phrase, they will pray and will enter into a time of quiet resting in God. If some word or phrase speaks in a special way to them, they will write down what God might be trying to teach through what they read.

\section{Invitation of Prayer to Different Churches}

An invitation will be sent to different churches in the Mizo Conference to pray for the particular villages that have been entered. Those working in the different villages will be asked to share prayer requests with some of the local churches asking for the church members to pray fervently for a particular period of time. The Early Church's method of praying for the disciples and for the gospel will be applied in this method.

\section{Holy Spirit}

As was mentioned in Chapter 2, the Holy Spirit plays an important role in the ministry. This aspect cannot be neglected, so the seminar will emphasize the vital role of the Holy Spirit in ministry. The interaction of the Holy Spirit in the life of Jesus, John the Baptist, and the Apostles will be studied. The Scripture tells us that Jesus was anointed and filled with the Holy Spirit before he started His ministry. "The spirit of the Lord is on me, because he has anointed me to preach good news to the poor" (Luke 4:18). 
The Holy Spirit played an important role in Jesus Christ's ministry. "Jesus full of the Holy Spirit returned from the Jordan and was led by the Spirit in the desert" (Luke 4:1). The power of the Holy Spirit can be seen in the ministry of Jesus Christ. The Bible says, "Jesus returned to Galilee in the power of the Spirit and news about Him spread through the whole countryside. He taught in their synagogues, and everyone praised Him" (Luke 4:14). John was filled with the Holy Spirit from the time he was conceived and was filled with the Holy Spirit in the desert before he started his ministry (Luke 1:15, $80)$.

The ministries of the Early Church were successful because they all were guided by the Holy Spirit (Acts 2:4). Wiersbe (1997) mentions the powerful interaction of the Holy Spirit, "When we are filled with the Spirit, we are energized by the Spirit-thinking, desiring, and doing what the Spirit wills for us" (p. 107). Wiersbe quotes Spurgeon: "To us, as ministers, the Holy Spirit is absolutely essential. Without Him our office is a mere name, if we have not the Spirit which Jesus promised, we cannot perform the commission which Jesus gave" (p. 110).

\section{Preach With Power}

Many workers among the Reang tribe cannot read English to enrich their knowledge with preaching books and those who can read do not have access to many books. They need training and materials to enrich their preaching. The Apostle Paul said, "My message and my preaching were not with wise and persuasive words, but with a demonstration of the Spirit's power, so that your faith might not res on men's wisdom, but on God's power" (1 Cor 2:4-5). Shriver (2005) has written, "God's word persuades 
most powerfully not only when it is heard, but when it is both heard and seen in the life of the one who proclaims it" (p. 25).

Preaching must be powerful and convincing to reach the hearts of the Reang people. The workers will be trained to understand that they need the power of the Holy Spirit to have influential preaching. The workers need to understand that they need to get fresh messages from God and convey those messages to the Reang people. God knows clearly the messages that need to be emphasized or related to current situations and challenges of the Reang people. White (1915) says that workers are needed who walk daily with God and maintain a living connection with heaven; their words will have power to bring conviction to hearts (p. 33).

White (1915) continues,

From his quiet retreat he watched the unfolding of events. With vision illuminated by the Divine Spirit he studied the character of men, that he might understand how to reach their hearts with the message of heaven. The burden of his mission was upon him, in solitude, by meditation and prayer; he sought to gird up his soul for the lifework before him. (p. 57)

Teaching Adventist doctrine is important but reaching the people's hearts with compassionate love is a priority. The Reang people need more concern and love than they need doctrinal presentations. Swears (2000) quotes Gregory the Great, "Doctrine taught does not penetrate the minds of the needy, if a compassionate heart does not commend it to the hearts of hearers" (p. 17).

Anderson (2001) refers to F. Buechner and talks about the concern and love for the people who are being served. "To preach the Gospel is not just to tell the truth but to tell the truth in love, and to tell the truth in love means to tell it with concern not only for 
the truth that is being told but with concern also for the people it is being told to" (p. 128).

In the seminar the methodology of Jesus' preaching will be examined. The workers must understand that Jesus practiced what he preached. His life was a living example and full of action that is in harmony with His preaching. Shriver (2005) points out the methodology of Jesus Christ,

Jesus, the Word, made his dwelling among us. He came full of grace and truth. He communicated. He preached. He made the Father known. How? John chapter one tells us. Jesus, the perfect preacher, communicated God's life changing word not just by speaking the truth but also by being the truth in our midst. Yes, the words of Jesus preached. But so did his life. In Christ's earthly ministry the Word wasn't just heard, it was seen. (p. 29)

The preacher needs to understand he is only the agent. He cannot do the work of convicting, convincing, and converting the hearts. Briscoe (2004) says, "The work of convicting, convincing, and converting is the Spirit's, not the preacher's and accordingly the preacher must learn to be the agent of the Spirit's working" (p. 26). The following quotations from Briscoe are helpful in order to have powerful preaching:

1. "The preacher must be plugged in to a source of power other than purely human," (p. 26).

2. "The greatest care must be taken to ensure that nothing in the preaching detracts from the person of Christ or does damage to the message of the gospel," (p. 32).

3. "The preacher who grips an audience is the preacher who is obviously gripped by the message," (p. 35).

4. "I preached as never sure to preach again and as a dying man to dying men," (p. 35).

\section{Commitment and Steadfastness}

The workers need a hearty commitment to do ministry among the Reang tribe.

The Reang tribe lives in the remote areas without electricity, water supply, proper sanitation, transportation, grocery stores, hotels, or accommodations. These are the 
visible obstacles that workers face in order to reach the Reang community. It is important to have training that will build up the commitment of the worker as these obstacles can bring a variety of disappointments to them. The disappointment of one worker can affect others, and disturb the ongoing ministry.

Without commitment it is not possible to do the work of God in the Reang community. It is better not to bring workers who do not have a solid commitment as this may bring disappointment and discouragement to their fellow workers. The seminar will allow time for the workers to examine their commitment for ministry. If it happens that they do not have a deep commitment they will be given freedom to cease their work in the community, but hopefully they will decide to stay and serve.

As servants of God, leaders are not to be easily discouraged by difficulties or opposition. White (1915) says,

God is trying to give us a lesson from our disappointment and apparent failure and His purpose is to master difficulties. He inspires us with a determination to prove every apparent failure a success. We may pray and weep because of the perplexities and obstacles but we need to hold fast until the end and God will be there. Our success from apparently insurmountable difficulties will bring greatest joy (p. 269).

There are many hardships and responsibilities that need to be confronted by those doing ministry in the Reang community and the Spirit of Prophecy can be a real comfort for the workers. White (1915) says that the true minister of God will not avoid hardship or responsibility. God is always ready to help the worker if that person sincerely seeks His guidance and divine power. God's worker can obtain strength that will prepare him or her to meet and overcome temptation and to continue the duties that God places upon $\operatorname{him}($ p. 108).

The workers among the Reang community need to work without reserve and face 
the difficulties ahead of them with God's promises. White says (1915) says that men are needed who will consecrate themselves without reserve to do the work of God to a world dying in wickedness. The world is in need of men of thought, men of principles and who are constantly growing in understanding and discernment (p. 25). The person who can work without reserve and just depend on God's leading is needed to meet the needs of the Reang tribe.

White (1911) wrote that every worker who wants to follow the example of Christ will be prepared to receive and use the power that God has promised to His church. If the workers will kneel down before the Lord to renew their vows of consecration every morning, God will pour His spirit of reviving, sanctifying power on them. When they go out for their daily duties, they go with assurance of the Holy Spirit that will enable them to work with God (p. 56).

\section{Discipleship}

In current methodology, the Mizo Conference workers are trying to convey the Adventist truth to the Reang community. The subject of discipleship is not very well understood and the obligation of discipleship is often omitted in our teaching. The believers need to understand the commitment they need to have in making a decision to follow Jesus Christ and receive His transformation if they are to convey the same message they received.

Making disciples who can make another disciple is the method Jesus implemented in His ministry. Before a person makes a decision for baptism it is very important that he or she understand the role of discipleship. After entering the body of Christ and joining the church, discipling must take place to develop spiritual growth. 
The purpose of the discipleship training is to prepare workers to become discipleship trainers. It is hoped that this training will change their attitude towards new believers and help them to understand the role of a disciple and the responsibility of discipleship. The workers need to understand first the role of discipleship to convey the same spirit to the Reang believers. Our future may not look bright in the current situation but the disciples in the past followed Jesus whatever it cost them. This same spirit must reach the hearts of the Mizo Conference workers and then impact the Reang believers.

White (1915) has written about the attitude of discipleship.

When Christ called His disciples to follow Him, He offered them no flattering prospects in this life. He gave them no promise of gain or worldly honor, nor did they make any stipulation as to what they should receive. To Matthew as he sat at the receipt of custom, the Savior said, "Follow Me." And he arose, and followed Him. (Matt. 9:9). Matthew did not, before rendering service, wait to demand a certain salary, equal to the amount received in his former occupation. Without question or hesitation he followed Jesus. It was enough for him that he was to be with the Savior, that he might hear His words and unites with Him in His work. (p. 113)

The discipleship training with the workers will enable the Reang believers to understand the role they also can play in ministry. The workers will be able to guide the Reang believers to understand that the concept that they have freely received so they must now freely give (Matt 10:8). If they are trained to take part in ministry God's work will be strengthened in the Reang community in various ways. They will be trained to become faithful witnesses for the Lord and Ellen White's prophecy will be fulfilled in the Reang Community when she said, "Where there is now one minister in the field, twenty are to be added; and if the Spirit of God controls them, these twenty will so present the truth that twenty more will be added" (White, 1915, p. 65). 


\section{Follow Up to Nurture the Reang Believers}

The new converts need guidance to understand the importance of depending on God in their spiritual growth. One of the important steps that must not be neglected is follow-up methods, nurturing them into spiritual maturity and helping them to play the true role of discipleship.

According to my personal observation and experience in our ministry among the Reang tribe, we focus much of our time in entering into new areas and neglecting most of the areas we have entered. If we give more time to the area we entered to nurture the people, it will definitely bring better changes in their community.

\section{Stay With Them}

I believe that too often we do not give enough time to the new believers to give them a knowledge of the Word of God and help them in their spiritual growth. Jesus stayed with his disciples and taught them the Word of God. If the same methodology is applied to the Reang believers to teach them the Word of God, then an understanding of their difficulties and challenges are needed to more effectively bring spiritual growth.

The workers need to stay with the Reang people to apply the same methods of Jesus. The first challenge will be accommodation for the workers. They do not have good housing or extra houses for accommodation. It is necessary to build a house for the minister and a meeting hall for Bible study and worship before the church building is erected.

To stay with the Reang tribe in the remote areas, the workers need to set up their own housing if there is no government building available for rent. Since there is no good 
accommodation, sanitation, or water reservoir, the workers can easily become sick. Malaria and other contagious diseases are prevalent in the communities so it is really important to have a house where the worker can stay for long periods of time to do the work of nurturing. The meeting hall is also needed immediately as the tribe does not have big houses to accommodate many people. The meeting hall can later be used for the Sabbath worship service and for prayer meetings.

\section{Training a Few People}

The methodology of Jesus will be applied: the plan is to train a few people, especially young people, who will be able to convey the message to their community. This training will be one of the important steps to nurture the Reang tribe and bring successful growth in their spiritual growth. A survey will be done to find the young people who can be helpful to future ministries. These chosen people who are capable of going for further education will be sent to the seminary to enrich their knowledge. There are also some students who are currently attending the seminary but more people are needed to be able to have an influence on the whole community. For those who.are not sent to the seminary, the training will be given through ongoing in-service training. The involvement in the ongoing ministry will give them experience and prepare them for future ministries. In order to implement this program, funds will be collected from various sources.

\section{Choir Groups}

Choir groups have already been formed in some places with the intention that more groups will be formed in other places. The choir groups will visit different churches 
to motivate the new believers and uplift their spiritual lives. The young people who have talents in singing and preaching will be given special guidance to make use of their talents. This program will help enhance the young people's talents as they influence their community with the Adventist message.

\section{Bible Study Classes}

Since an evangelistic meeting cannot cover all the important topics of the Bible within a few weeks, local workers will need to continue with Bible study classes after the meetings are over. These classes will be held on Sabbath afternoon and on week days. The goal is to allow God's Word to replace the local indigenous beliefs and lifestyle of the people. Hull (1984) emphasizes four fundamentals that need to be established in the Christian growth:

The Christian must be established in these four fundamentals: the word, prayer, fellowship, and witnessing. Whatever he becomes in later life, regardless of the skills he acquires, he will be only as strong as he is in the fundamentals. This never changes; there is no other way to become a consistent disciple. (p. 76)

The Reang new believers need special nurturing because their indigenous beliefs have a powerful impact on their lives in various ways. There are some subjects that need more emphasis such as tithing, Sabbath-keeping (especially the creation story), marriage, the state of the dead, temperance, spiritual discipline, faithfulness, importance of hard work, cleanliness, etc.

For example, returning the tithe with their current condition of daily survival is one of the important areas that needs to be emphasized. They have a hard time participating in the returning of tithe. They need to understand that faithfulness to God will bring many more blessing to their life. White (1940b) says, 
It is part of the minister's work to teach those who accept the truth through his efforts, to bring the tithe to the storehouse, as an acknowledgment of their dependence upon God. The new converts should be fully enlightened as to their duty to return to the Lord His own. The command to pay tithe is so plain that there is no semblance of excuse for disregarding it. He who neglects to give instruction on this point, leaves undone a most important part of his work. (p. 105)

Bible study will gradually change the attitude and concept of their worldview. The subjects that need to be emphasized would be taught to the workers in various places.

The media has great influence among the Reang community; it can easily gather the whole community in various places. Since the majority of the people do not read, visual aids would be a helpful means to impart the Word of God to their minds and replace their animist beliefs. The challenge is that there is not enough media to do this, and to use media a generator is needed as many remote areas are without electricity.

\section{Family Worship}

In their indigenous beliefs they used to pray by kneeling and holding their hands together when they made offerings of fruits, nuts, or sweets to their god, which was then blessed by their god before being eaten. The family worship can be redirected to the true God, and used to introduce them to new patterns of Christian family worship.

The Reang indigenous religious practices do not have regular family worship. They just do it whenever they feel like doing it. It is very important to introduce family worship and to help them practice it in their daily lives. They need practice and guidance to adapt the forms of Christian worship. The level of their practice may be different at the beginning but will change as their family worship practices are evaluated every two weeks by the Bible workers. Guidance will be given according to their improvements and the changes they need to make. 


\section{Prayer Meeting}

Prayer meetings should be held once a week. The Reang tribe sacrifices their animals such as goats and chickens to appease their god. The sacrificial system in the Bible can be related to them as Christ has given the supreme sacrifice for all of us (Heb 10). If they understand that prayer replaces the sacrificial system, the believers can reach to God peacefully with their prayers without doing any sacrifice. The prayer meeting will be conducted with the intention of eliminating their previous beliefs of the sacrificial system. The previous sacrificial system would be re-directed to prayer where they can share all their problems and difficulties. Prayer meeting will help them to understand the meaningless of their previous sacrificial system, and the usefulness of the prayer meeting where they can offer everything to the Lord in prayer.

In the prayer meeting the study of the importance of personal prayer and devotions will be included. There will also be a sharing time when they can share their personal experience with prayer and devotions. If they need further assistance the minister will direct them individually.

The daily prayer uplifts the soul and the new believers must be taught to have a daily communion with God. White (1973) says,

When Jesus was upon the earth, He taught His disciples how to pray. He directed them to present their daily needs before God, and to cast all their care upon Him. And the assurance He gave them that their petitions should be heard, is assurance also to us. (p. 290)

White (1973) wrote, "Religion must begin with emptying and purifying the heart, and must be nurtured by daily prayer" (p. 290). 
Visitation

There are two types of visitation that can be helpful to nurture the Reang believers. Through the pastoral visitation and church-to-church visitation the spiritual needs of the individual and the community can be met.

\section{House-to-House Visitation}

The workers will be trained to not neglect visiting different homes to care for personal, physical, and spiritual difficulties. The Reang people are usually shy and timid so rarely open up and share their problems before having a close relationship. Therefore, it is necessary to reserve enough time to deal with different families and individuals.

\section{Church-to-Church Visitation}

The new believers in the different churches will also be encouraged to visit each other. The details of the timely routine can be planned by the minister. This program is to strengthen the newly established churches in various places. This will open up more time for Christian fellowship, and will give them time to share the joys and difficulties in their Christian lives. As many churches will face problems with transportation, lodging, and food, an amount of money should be budgeted or raised particularly for this program of church visitation. This program will be designed to be implemented during the first two years after new believers join the Adventist Church. After they are established in the church and have improved their financial condition, then the workers will do an evaluation of those churches and make up a program according to their needs. 


\section{Adult Literacy Class}

The majority of the Reang tribe in the village areas is not able to read and write. Reading and writing classes will be held for the Reang adults. Since they cannot read and write they cannot access the Word of God in their personal devotions to improve their spiritual lives. An adult literacy class should enrich their daily devotions and enable them to access the inspired writings from the Bible and the Spirit of Prophecy.

\section{Translation of Spirit of Prophecy Books}

The translation of the Spirit of Prophecy books by Ellen White is very important in order for successful nurturing to take place. At this time they do not have any Spirit of Prophecy writings in their own dialect. A fund will be instituted to pay for translation of as many as possible writings of Ellen White. Since many of them would not be able to afford to buy the books, it would be necessary to raise funds to be able to subsidize the costs of the books.

\section{Sabbath School}

Sabbath School programs can play an important role in nurturing the Reang believers, especially if time is taken to focus on God's creation. The majority of the believers have an animist background so would need further explanation about the Creator and creation. The nature talks in Sabbath School should focus more on the creation story and subjects that will build up the people's faith.

Many people in the Reang community cannot read the Sabbath School lessons; therefore, in the first few months after learning about God a study of the creation story 
during the Sabbath School lesson time would be excellent. Since the Bru mostly live near the forest and if the weather is good, they could be taught out in nature as Jesus did with his listeners. The Bru should also be given time to share their beliefs and ideas. This sharing time would help the workers to see their beliefs and help them to approach them according to their needs.

\section{Conclusion}

The remnant church is called to accomplish a specific ministry in the last days. The ministry that leads to conversion includes a life-long process of spiritual nurture that fosters the growth of the Christian character.

The biblical model of "churching" indicates that baptism is not the end but the beginning of the process of the spiritual maturation of the believers. Believers are guided and nurtured through their life span in their spiritual journey by a well-established ministry of spiritual nurture facilitated by the gifts of the Spirit.

God knows the needs of the Reang people and He can give guidance to uplift their situation in various ways. God should be the main one to initiate the plan we are trying to implement among the Reang tribe. We are not to invite the Holy Spirit to help in our plans; rather the Holy Spirit should initiate those plans. God is rich enough to supply all needs at the right time and in the right place. We cannot use the Holy Spirit; the Spirit is to use us. Through the Spirit, God works in His people "to will and to do of His good pleasure" (Phil 2:13).

I previously had a strong feeling that spiritual nurturing among the Reang tribe could not be done without doing physical development to ease their daily struggles, but this dissertation has changed some of my previous attitudes. God is the one who does the nurturing, who knows every need of the Reang tribe, and who can supply everything they 
need. If we are filled with the Holy Spirit and work with the guidance of the Holy Spirit, the Holy Spirit will prompt us to do the spiritual work and help with the physical needs of the people. White (1915) says,

The impartation of the Spirit is the impartation of the life of Christ. Those only who are thus taught of God, those only who possess the inward working of the Spirit, and in whose life the Christ-life is manifested, can stand as true representatives of the Savior" (p. 285).

A true representative of the Savior is needed to bring changes and nurture the heart of the Reang tribe.

I often wonder what must be our goal in doing nurturing. How do we nurture the new believers towards Christian perfection and spiritual maturity? This project has given me a deeper understanding of nurturing, the processes of helping a believer to understand the need of Christ in every detail of the Christian growth.

White's (1915) encouraging words can be appropriate to meet the challenge among the Reang Tribe,

In order for a man to be a successful minister, something more than book knowledge is essential. The laborer for souls needs consecration, integrity, intelligence, industry, energy, and tact. Possessing these qualifications, no man can be inferior; instead, he will have a commanding influence for good. Those who consecrate body, soul, and spirit to God, will constantly receive a new endowment of physical, mental, and spiritual power. The inexhaustible supplies of heaven are at their command. Christ gives them the breath of His own Spirit, the life of His own life. The Holy Spirit puts forth His highest energies to work in heart and mind. The grace of God enlarges and multiplies their faculties, and ever perfection of the divine nature comes to their assistance in the work of saving souls. Through co-operation with Christ, they are made complete in Him, and in their human weakness they are enabled to do the deeds of Omnipotence. (p. 112) 


\section{REFERENCE LIST}

Adsit, C. B. (1988). Personal disciple-making: A step by step guide for leading a Christian from new birth to maturity. San Bernardino, CA: Here's Life Publishers.

Anderson, K. C. (2001). Preaching with conviction: Connecting with the listeners. Grand Rapids, MI: Kregel.

Andreasen, M. L. (1937). The sanctuary service. Washington, DC: Review and Herald.

Armstrong, D. W. (1983). Evangelistic Growth in Acts 1\&2. Nashville, TN: Broadman Press.

Arn, W., \& Arn, C. (1998). The master plan for making disciples. Grand Rapids, MI: Baker Books.

Barker, S., Johnson, J., Malone, R., Nicholas, R., \& Whallon, D. (1985). Good things come in small groups: The dynamics of good group life. Downers Grove, IL: InterVarsity.

Ball, C. F. (1996). The life and times of the Apostle Paul. Wheaton, IL: Tyndale House.

Barna, G. (2001). Growing true disciples. Colorado Springs, CO: Water Brook.

Blackaby, H. T., \& Blackaby, R. (2001) Spiritual leadership: Moving people on to God's agenda. Nashville, TN: Broadman \& Holman.

Blackaby H. T., \& King, C. V. (1994). Experiencing God. Nashville TN: Broadman \& Holman.

Blackaby, H. T., \& King, C. V. (1998) Experiencing God: Knowing and doing the will of God. Nashville, TN: Broadman \& Holman.

Briscoe, S. (2004). Preach it. Loveland, CO: Group Publishing.

Brown, S. (1994). If God is in Charge. Grand Rapids, MI: Baker Books.

Burrell, D. J., \& Burrell, J. D. (1897). Early church: Studies in the Acts of the Apostles. New York: American Tract Society. 
Coleman, R. E (1964). The master plans of evangelism. Old Tappan, NJ: Fleming H. Revell Company.

Coleman, R. E. (1987). The master plan of discipleship. Old Tappan, NJ: Fleming H. Revell Company.

Coleman, R. E. (1997). The master's way of personal evangelism. Wheaton, IL: Crossway Books.

Conant, J. E. (1922). Every member evangelism. New York: Harper \& Brothers.

Crabtree, C. T. (2003). Pentecostal preaching. Springfield, MO: Gospel Publishing House.

Debbarma, S. (2005). The Reangs of Tripura. In S. K. Chaudhari \& S. S. Chaudhari (Eds.), Primitive in Contemporary. Mohan Garden, New Delhi: Krishna Mittal.

Dev, C.R. (2009). The Reangs of Tripura. Retrieved from http://www.indianfolklore.org/journals/index.php/Ish/article/viewArticle/562

Graham, B. (1978). The Holy Spirit. Waco, TX: Wordbooks.

Greenleaf, R. K., Spears, L. C., \& Covey, S. R. (2002). Servant leadership: A journey into the nature of legitimate power and greatness (25th ed.). Mahwah, NJ: Paulist Press.

Hanks, B., \& Shell, W. A. (1993). Discipleship: Great insights from the most experience disciples makers. Grand Rapids, MI: Zondervan.

Henrichsen, W. A. (1988). Disciples are made not born. Wheaton, IL: SP Publications.

Honeycutt, R. L. (1969). Exegesis in the book of Exodus. In C. J. Allen (Ed.), The Broadman Bible Commentary (17:305-472). Nashville, TN: Broadman.

Hull, B. (1984). Jesus Christ disciple-makers. Colorado Springs, CO: Navpress.

Kouzes, J. M., \& Posner, B. Z. (2007). The leadership challenge (4th ed). San Francisco, CA: Jossey-Bass.

Kreider, L. (2007). Authentic spiritual mentoring: Nurturing young believers toward spiritual maturity. Ventura, CA: Regal.

Lawless, C. (2002). Disciple warriors: Growing healthy churches that are equipped for spiritual warfare. Grand Rapids, MI: Kregel Publications. 
Macarthur, J. (2005). Pastoral ministry: How to shepherd biblically. Nashville, TN: Nelson Reference \& Electronic.

Mallison, J. (1989). Growing Christian in small groups. Home Bush West, NSW: Anzea.

Martens, E. A., \& Swartley, W. M. (1993). Believers church commentary. Scottdale, PA: Herald Press.

McNeal, R. (2000). A work of heart: Understanding how God shapes spiritual leaders. San Francisco, CA: Jossey-Bass.

Melbourne, B. L. (2007). Discipleship: Lessons from the life of Jesus. Nampa, ID: Pacific Press.

Merrill, D., \& Shelly, M. (1984). Fresh ideas for discipleship \& nurture. Carol Stream, IL: Christianity Today.

Mills, S. (2010). Conserving the Harvest: First Steps for New Believers, p. 2 .

Retrieved from http://webuildpeople.ag.org/WBP_library/9802_firststeps.cfm

Mizo Conference Record Book, 2010.

Morton, S. (2003). Down to earth discipling: Essential principles to guide your personal ministry. Colorado Springs, CO: Nav Press.

Nee, W. (1996). The glorious church: Anaheim, CA: Living Stream Ministry.

Nichol, F. D., (Ed.). (1978). The Seventh-day Adventist Bible commentary (SDABC). Washington, DC: Review and Herald.

Oswalt, J. N. (2008). Exegesis of the book of Exodus. In P. W. Comfort (Ed.), Cornerstone Biblical Commentary (16:259-558). Carol Stream, IL: Tyndale House.

Pentecost, D. J. (1996). Design for discipleship: Discovering God's blue print for the Christian life. Grand Rapids, MI: Kregel.

Ruby, L. A. (1992). Empowering God's people: Rediscovering the person and work of the Holy Spirit in the contemporary church. Ann Arbor, MI: A Bell\& Howell.

Rylaarsdam, J. C. (1980). Exegesis of the book of Exodus. In G. A. Buttrick (Ed.), The interpreter's Bible (3:831-1099). New York: Abingdon.

Samanta, R. K. (1980). The Reang of Tripura: Socio-Cultural and Agro Economic Changes. Social Scientist 9/5/6 (Dec 1980-Jan 1981): 44-54). 
Schilt, W. C. (1992). Dynamic small groups: How to make them happen. Hagerstown, MD: Review and Herald.

Shriver, D. (2005). Nobody's perfect: But you have to be. Grand Rapids, MI: Baker Books.

Stanger, F. B. (1989). Spiritual formation in the local church. Grand Rapids, MI: Francis Asbury.

Stowe, E. L. (1976). The ministry of shepherding. Kansas City, MO: Beacon Hill Press.

Swears, T. R. (2000). Preaching to head and heart. Nashville, TN: Abingdon.

Sweetland, D. M. (1990). Our journey with Jesus: Discipleship according to Luke-Acts. Collegeville, MN: Liturgical.

Van Rheenen, G. Missions: Biblical foundations \& contemporary strategies. Grand

Rapids, MI: Zondervan. Retrieved from http://www.missiology.org/ essentialtasks/nurturingchristians.htm

White, E. G. (1886a). Letter 60. Published in Evangelism (1970). Washington, DC: Review \& Herald.

White, E. G. (1886b). Letter 48. Published in Evangelism (1970). Washington, DC: Review \& Herald.

White, E. G. (1888a). MS 13. Unpublished manuscript. Ellen G. White Research Center, Andrews University, Berrien Springs, MI.

White, E. G. (1888b). MS 8a. Unpublished manuscript. Ellen G. White Research Center, Andrews University, Berrien Springs, MI.

White, E. G. (1894). MS 42. Unpublished manuscript. Ellen G. White Research Center, Andrews University, Berrien Springs, MI.

White, E. G. (1896 April 28). The Advent Review and Sabbath Herald. Takoma Park Station, Washington, DC: Review and Herald.

White, E. G. (1897a). Letter 50. Published in Evangelism (1970) Washington, DC: Review \& Herald.

White, E. G. (1897b, September 28). The Advent Review and Sabbath Herald. Takoma Park Station, Washington DC: Review and Herald. 
White, E. G. (1898). MS 63. Unpublished manuscript. Ellen G. White Research Center, Andrews University, Berrien Springs, MI.

White, E. G. (1905). Letter 279. Published in Evangelism (1970) Washington, DC: Review \& Herald.

White, E. G. (1907 February 14). The Advent Review and Sabbath Herald. Takoma Park Station, Washington D.C: Review and Herald.

White, E. G. (1911). The Acts of the Apostles. Mountain View, CA: Pacific Press.

White, E.G. (1915). Gospel Workers. Washington, DC: Review \& Herald.

White, E. G. (1940a) The Desire of Ages. Mountain View, CA: Pacific Press.

White, E. G. (1940b) Counsels on Stewardship. Washington, D.C.: Review and Herald.

White, E. G. (1941) Christ's Object Lessons. Hagerstown, MD: Review\& Herald.

White, E. G. (1942) Ministry of Healing. Mountain View, CA: Pacific Press.

White, E. G. (1948a). Testimonies for the Church (Vol. 4). Mountain View, CA: Pacific Press.

White, E. G. (1948b) Testimonies for the Church (Vol. 5). Mountain View, CA: Pacific Press.

White, E. G. (1948c) Testimonies for the Church (Vol. 7). Mountain View, CA: Pacific Press.

White, E. G. (1970). Evangelism. Washington, DC: Review \& Herald.

White, E. G. (1973). God's Amazing Grace. Washington, DC: Review \& Herald.

White, E. G. (1958). Patriarchs and Prophets. Washington, DC: Review \& Herald.

White, E. G. (1995). Pastoral Ministry. Silver Spring, MD: General Conference Ministerial Association.

White, E. G. (2002). Testimonies on Sabbath School. Washington, DC: Review \& Herald.

Wicker, J. J. (1944). The march of God in the age long struggle. Nashville, TN: Broadman Press. 
Wilhoit, J. C. (2008). Spiritual formation as if the church mattered: Growing in Christ through community. Grand Rapids, MI: Baker Academic.

Wiersbe, D. W. (1997). 10 power principles for Christian service: Ministry dynamics for a new century. Grand Rapids, MI: Baker Books.

Wiersbe, D. W. (2000). The dynamics of pastoral care. Grand Rapids, MI: Baker Books.

Wofford, J. C. (1999). Transforming Christian leadership: 10 exemplary church leaders. Grand Rapids, MI: Baker Books.

Young, T. (2004). After the fishermen: How did Jesus train his disciples? Tottenham Court Road, London, UK: Paternoster. 
VITA

Name Lalmuansanga Chawngthu

Date of Birth April 23, 1975

Married December 9, 1999, with Lalthangveli

\section{Education}

1995-1998 B.L.A. in Religion, Spicer Memorial College, Poona, India

2001-2002 M.A. in Religion, Spicer Memorial College, Poona, India

2007 D.Min. in Leadership, Seventh-day Adventist Theological Seminary, Andrews University, Berrien Springs, MI USA

\section{Diplomas Earned}

2006

Health Evangelism \& Preventive Medicine, Pacific Health Education Center, Bakersfield, CA USA

\section{Employment}

1999-2000 Conference Evangelist, Lawngtlai, Mizoram, Mizo Conference of S.D.A. Mizoram, India

2004-2007 Conference Evangelist, Tlangsang, Tripura, Mizo Conference of S.D.A. Mizoram, India 